\title{
A fuzzy logic methodology for assessing the resilience of past communities to tephra fall: a Laacher See eruption 13,000 year BP case study
}

\author{
Russell Blong $^{\star \alpha}$, Felix Riede ${ }^{\beta}$, Qianyang Chen $\gamma$ \\ ${ }^{\alpha}$ Risk Frontiers, 2/100 Christie St., St Leonards, NSW 2065, Australia \\ $\beta$ Laboratory for Past Disaster Science, Department of Archaeology and Heritage Studies, Aarhus University, Moesgård Allé 20,8270 \\ Højbjerg, Denmark

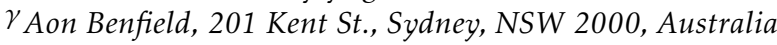

\begin{abstract}
While volcanologists are experienced in assessing present and past volcanism, and while archaeologists are experts in understanding past societies, the study of how ancient volcanic activity has impacted contemporaneous communities remains little systematised. We here present a fuzzy logic-based methodology for bringing together expert assessments in evaluating the vulnerability and, by extension, the resilience of a group of late Pleistocene foragers to the Laacher See eruption 13,000 years ago. Based on attributes assessing human health, shelter, food supply, and water supply our analyses suggest community resilience falls as tephra fall thickness increases. Our explicit assessment of different experts' evaluation of the different attributes' relative importance facilitates a rigour in formulating such impact scenarios. The methodology can be readily transferred between case studies and, in principle, between hazards, and could contribute significantly to the design of realistic disaster scenarios.
\end{abstract}

\section{ZUSAMMENFASSUNG}

Vulkanologen sind erfahren sind in der Beurteilung von gegenwärtigem und vergangenem Vulkanismus, Archäologen Experten im Verstehen vergangener Gesellschaften. Es gibt jedoch nur wenige systematische Ansätze zum Studium historischer und prähistorischer Eruptionen und deren sozio-ökologischen und sozio-kulturellen Einflüsse. Wir stellen hier eine auf Fuzzy-Logik basierende Methodik zum Zusammenführen von Expertenbewertungen hinsichtlich der Vulnerabilität und ihres Gegenstücks der Resilienz einer spätpleistozänen Jägergruppe auf den Laacher See Ausbruch um 13.000 BP vor. Die Attribute Gesundheit, Obdach, Nahrungsmittelversorgung und Wasserversorgung werden bewertet. Resilienz fällt, wenn die Mächtigkeit der Tephradecke zunimmt. Die explizierte Bewertung der unterschiedlichen Experten hinsichtlich der relativen Bedeutung der verschiedenen Attribute erleichtert die Formulierung eventueller Folgeszenarien. Die Methodik kann problemlos zwischen Fallstudien und Hazard-Typen übertragen werden und könnte erheblich zur Gestaltung realistischer Katastrophenszenarien beitragen.

Keywords: Resilience; Tephra fall; Laacher See eruption;

Fuzzy logic methodology; late Pleistocene foragers ; Vulnerability

\section{InTRODUCTION}

A large literature attributes demise or other change in cultural trajectories to the impact of a disaster. In particular, volcanic eruptions stand out as potential and much discussed catalysts for such dramatic changes, ranging from the potentially catastrophic global impact of the Toba super-eruption 74,000 years BP on Homo sapiens [Jones 2015], to the Campanian Ignimbrite Y5 eruption and its effects on Homo sapiens and Neanderthals alike in western Eurasia ca. 38,000 years ago

${ }^{*}$ Corresponding author: rblong43@gmail.com
[d'Errico and Banks 2015], to the wide-ranging impacts of the Thera eruption 3,600 years ago on Mediterranean societies [Risch and Meller 2013], to the cultural, political and demographic upheavals of the 6th century AD in Europe and elsewhere [Büntgen et al. 2016], and even to the Medieval period [McCormick et al. 2007]. These are merely selected examples from a wide palette of instances where past volcanic eruptions may have affected communities far and near [Sheets and Grayson 1979; Grattan and Torrence 2007; Grattan and Torrence 2003; Felgentreff and Glade 2008; Oppenheimer 2011; Cooper and Sheets 2012; Riede 2015]. 
Here, we propose a methodology that provides a semi-quantitative test of the impact of a specific volcanic hazard, tephra fall, on a culture and way of life by (a) setting the resilience of the culture pre-impact, then (b) estimating the impact of the disaster/extreme event by approximating values for the key attributes postimpact using fuzzy logic and weighted assessments of attribute vulnerability to varying thicknesses of tephra fall. We have chosen an event from the Late Pleistocene, the eruption of the Laacher See volcano in present-day Germany and its impact on contemporaneous forager communities [Riede 2008; Riede 2017b], to illustrate this exploration. Yet, we envisage that the proposed methodology, at varying levels of detail, could be used to elucidate and explore the changes likely produced by any disaster or extreme event - past, present or future. We see this methodology as an adjunct to the Realistic Disaster Scenario (RDS) approach [Davies et al. 2015] to evaluating the likely consequences of the impact of a natural hazard.

In this paper, we consider the impact of the Laacher See eruption (LSE) that occurred about 13,000 years ago [Schmincke et al. 1999; Baales et al. 2002] on a small group of people belonging to a late ice age cultural complex, the so-called Federmessergruppen (FMG), and living ca. $230 \mathrm{~km}$ northeast of the volcano in an area that received $5-20 \mathrm{~cm}$ of tephra fall. We begin by briefly reviewing the eruption and by then reconstructing as fully as possible the life and livelihood of these Palaeolithic people immediately prior to the eruption in terms of just four major attributes that we believe would be most affected by the eruption: human health, shelter, food supply, and water supply. We assign a value representing the resilience of this society to external shocks, then assess changes in societal resilience as a result of the eruption. Our aim is to determine, so far as is possible, and in as rigorous a way as possible, whether this society is likely to 'dive, survive or thrive' - all other factors being held constant post-eruption. Our time frame for the analysis is from immediately before the eruption to one to two years post-eruption, and with the more immediate impacts, although we fully acknowledge that some disaster impacts first become apparent after the initial perturbation. With a soundly-based view of the vulnerability of the society to changes imposed by the eruption and fall of volcanic ash we are in a position to examine with more certainty questions such as whether it is more likely that the group disappeared, remained in place, migrated, or explored other adaptive options, and hence to formulate hypotheses for further empirical exploration.

Vulnerability refers to the propensity of exposed elements (we call them attributes below) such as physical or capital assets, as well as human beings and their livelihoods to experience harm and suffer damage or loss when a community is impacted by a hazardous event [c.f. Adger 2006; Birkmann et al. 2013]. Vulner- ability may have many components - social, economic, cultural, institutional, physical or structural, and ecological [Cutter et al. 2003]. On the other hand, resilience focuses both on the ability of a vulnerable system to deal with the disturbing events and the effects of those stresses and, often, also on the regenerative abilities of a social system or an ecosystem.

Both vulnerability and resilience are fuzzy, multifaceted but overworked concepts, with nearly as many definitions as there are research studies across a range of disciplines, including archaeology [Redman 2005; Bradtmöller et al. 2017]. It is not always clear just what these terms stand for. Vulnerability or resilience can be defined by a score on a selected indicator, by a statistical analysis, by a multi-attribute profile, a relative index or by the outcome of a scenario. Here, we take the pre-eruption resilience of our target Federmessergruppen community to be 1.0: in this view, the Federmessergruppen form a semi-stable domestic (i.e. economically largely self-sustained) group living a demanding but socially, culturally, physically, ecologically, and institutionally balanced life. We do not regard the Federmessergruppen as passive acceptors of their vulnerability; they coped with a harsh environment characterised by weather and climate volatility but maintained a sustainable livelihood reflected in the longevity $(>1000$ years) of this way of life.

We then measure the reduction in resilience (if any) resulting from the impact of the Laacher See tephra fall on this community; in this sense, post-eruption Resilience $=1-V$ ulnerability. In effect, this empirical method matches that used in modelling the damage to, or the reduction in the value of, a physical asset such as buildings after the impact of a natural hazard [Walker 2011; Muir-Wood 2012].

Prima facie more substantive tephra fall relates to greater human impact. Total impact is suggested to increase with tephra thickness, although not uniformly across different attributes. Our explicit assessment of different experts' evaluation of the relative importance of the different attributes facilitates rigour in formulating such impact scenarios. The assessment methodology is rapid and can then be matched against existing evidence or, importantly, be used to also assess contemporary communities' potential for loss under different tephra fall conditions. The methodology can be readily transferred between case studies and hazards and could contribute significantly to the design of realistic disaster scenarios, which in turn serve to build resilience in at-risk communities.

\section{Before the LaAcher See eruption; the FEDERMESSERGRUPPEN}

Around the height of the last ice age, which peaked at ca. 22,000 years ago, northern Europe had become devoid of people. From 15,000 years BP, forager groups 


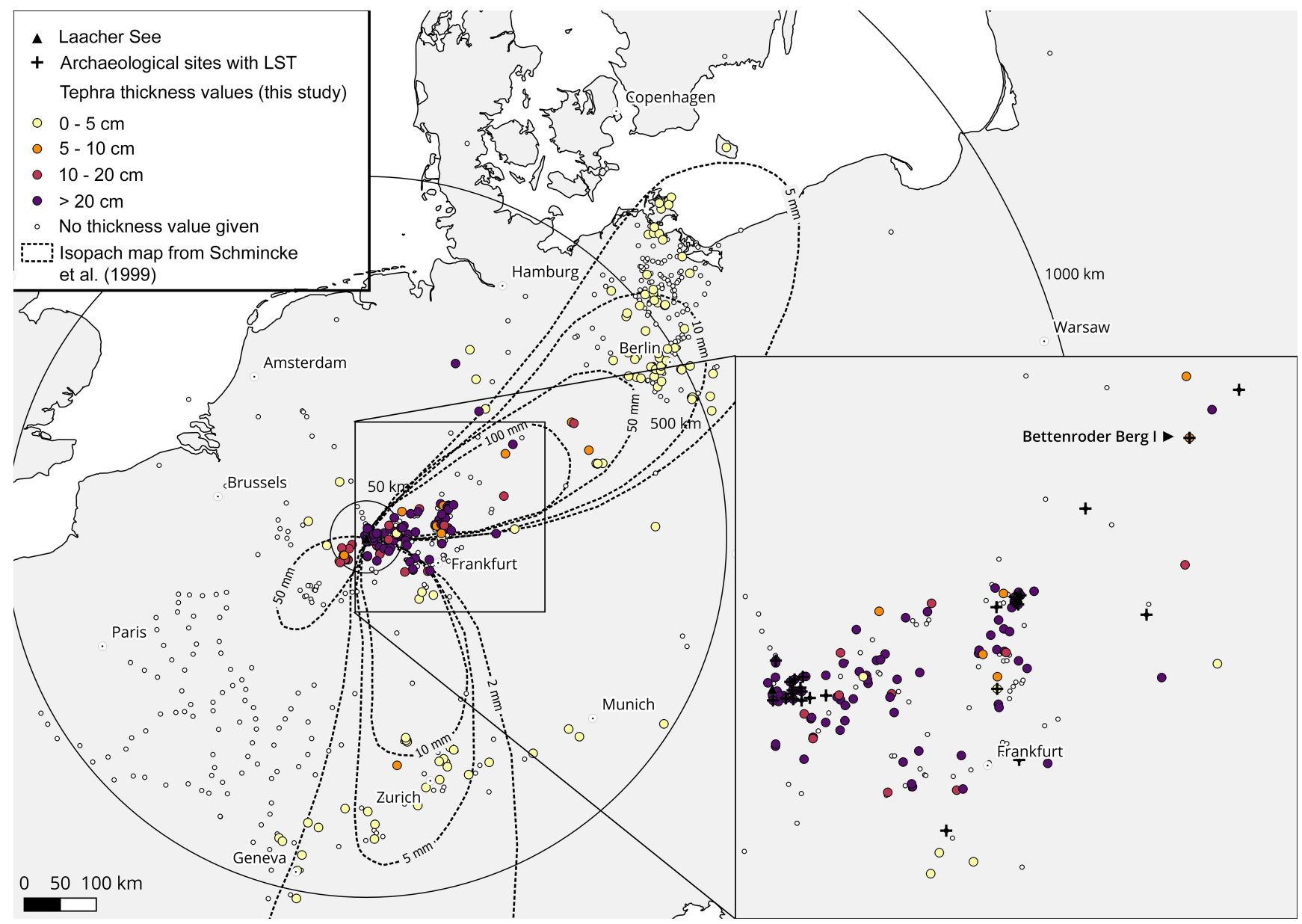

Figure 1: Late Glacial palaeogeograhic map showing the currently known extent of the Laacher See tephra fall in Europe. White dots mark locales where Laacher See tephra is found in association with Federmessergruppen archaeology. The concentric circles mark the division into the proximal $(0-50 \mathrm{~km})$, medial (50-500 km), distal $(500-1000 \mathrm{~km})$, and ultra-distal $(>1000 \mathrm{~km})$ hazard sectors.

again began to occupy these higher latitudes. During the first more pronounced warming, animals and plants also expanded their ranges and consolidated their communities [Riede 2014a]. While still immature and unstable, ecosystems akin to Boreal (taiga) mixed forest communities were developing in Central Europe, although it is worth noting that this period was characterised by unstable so-called non-analogue plant and animal species compositions, which find no match in the present [Sommer et al. 2011; Willerslev et al. 2014]. Stratified sites dating to the Late Pleistocene in the midfield of the Laacher See eruption's fallout are generally scarce. In the south, these tend to be cave sites, which do not present ideal sediment traps for airfall tephra. Consequently, no such sites are known as yet in that sector. To the west and the north-east, however, such sites are known and none preserve traces of human occupation following the LSE.

This section describes the life and livelihoods of one group of these foragers based on the evidence produced at the site of Bettenroder Berg I (51.4578 N; $10.0089 \mathrm{E})$ in the hilly regions along the River Leine near Göttin- gen (see Figure 1). During archaeological survey work [Grote and Freese 1982], evidence for human occupation was discovered under a shallow rock-shelter and in stratigraphic succession, where the Federmessergruppen occupation is capped by fallout tephra from the Laacher See eruption (LSE: Figure 2). Subsequent excavations at this and other nearby rock shelters have not only confirmed the stratigraphic observation of interrupted human presence in the area but have also produced several snapshots of human occupation on the eve of the Laacher See eruption [Grote 1988; Grote 1990; Grote 1994; Grote 2003]. At the locale Bettenroder Berg I, a small group of hunter-gatherers most likely consisting of a domestic family unit including men and women of different ages as well as children had settled for at least a few days. Their hunting trips in the surrounding light forests-forests dominated by birch, pine and willow trees-were successful, as indicated by the presence of bones from red deer (at Bettenroder Berg I), roe deer and wild boar (at the nearby and contemporaneous Bettenroder Berg IX; see Staesche [1994]). The remains of what most likely was 
a dog provide a glimpse into the hunting strategies of these open forest foragers. People had constructed a fairly substantial fire place and flooring using sandstone plaques. Flint-knapping activities using Baltic flint brought along from the excursions northwards and local lydite were used to produce the stone components of their weapons (e.g. the bow and arrow) and instruments. The volume of material recovered suggested a short-term occupation only, although the unusually high investment into the construction of flooring may indicate the original intention to stay longer - an intention that, according to the excavator, was cut short by the tephra fall [Grote 2003].

We hypothesise that the key structural domains for pre-eruption vulnerability at a given location are (a) health, (b) shelter, (c) food supply, and (d) water supply.

(a). Few human remains are known from this period in general and also in Germany specifically [Street et al. 2006]. One tantalising but so far impossibleto-locate human bone (cranium) has been reported from Dorla not far from Bettenroder Berg. This cranium is said to have been found directly underneath Laacher See tephra (LST: Fiedler [1994]), but attempts to locate this find have not been successful. These caveats aside, we are most likely dealing with overall healthy individuals that do not suffer from infectious disease load and where members of the older generation have experienced wear due to a life of very high mobility and great physical activity, as indicated by osteological investigations [Street et al. 2006].

(b). As regards shelter, it has been suggested that light skin tents were the most common form of habitation, but natural shelters such as overhanging rocks and shallow caves were used opportunistically [Jöris and Terberger 2001; Riede 2012].

(c). The people of the Federmessergruppen were hunter-gatherers with a focus on terrestrial mammals: red deer, roe deer and wild boar were commonly hunted in central Europe [Staesche 1994], while elk, perhaps reindeer, and possibly giant deer played a greater role further to the north [Bratlund 1993; Street 1996]. Small mammals such as the beaver [Baales and Street 1999] as well as fur-bearing animals such as the fox and rabbit were likely exploited for food as well as other resources [Charles 1997]. Freshwater fish were also becoming an important resource at this time [Le Gall 2003; Gramsch et al. 2013] as were edible plants (berries and fruit), although it is hard to know precisely which plant foods were consumed.

(d). Potable water was readily available in central and northern Europe. Although poor preservation may mar our picture here, there is no evidence for containers from this period so procurement of drink- ing water may have been immediate and embedded in other activities. The site of Bettenroder Berg I overlooks the River Leine, and sites from this period tend to be in proximity to freshwater sources [Sauer 2018].

\section{The LaAcher See eruption at a distance}

The Laacher See eruption is well-studied proximally and from a volcancological perspective. It was a VEI 6 phreatomagmatic eruption that tapped a strongly zoned magma chamber. The eruption column has been reconstructed to have been $<40 \mathrm{~km}$ high at its maximum. The eruption was at its most intense over a period of probably only a few days, but eruptive activity is likely to have lasted several months in total. A near-vent area of approximately $1400 \mathrm{~km}^{2}$ was covered in pyroclastic density currents and other ejecta in depths of between 1 and $50 \mathrm{~m}$. Thanks in particular to the detailed research of Hans-Ulrich Schmincke, the eruption and its sequence are now known in great detail (see, for instance, Schmincke [2004] and references therein). Similarly, a great deal of archaeological research has been focussed on the well-preserved sites underneath the protective ejecta in the eruption's nearfield [Baales 2002]. Between 50 and $500 \mathrm{~km}$ from the eruptive centre, the immediate hazard potential of pyroclastic density currents and tephra diminishes or is absent and indirect effects on weather and local ecologies come to the fore. [Thorarinsson and Grayson 1979; Simkin et al. 2001]. A number of archaeological sites in the north-eastern medial fallout zone are known: Rothenkirchen [Hofbauer 1992], Rüsselsheim LA122 [Loew 2005], Mühlheim-Dietesheim [Fruth 1979; Fruth 1994], Weinberg Schadeleben [Mania 2003] and a series of rock-shelter sites along the River Leine in northern central Germany [Grote 1994]. These sites are located 90 to $330 \mathrm{~km}$ from the Laacher See edifice, and the distal-most locale of Schadeleben preserves a layer of LST $<13 \mathrm{~cm}$. The large-scale open-case lignite mining in that area has revealed further outcrops of LST which suggest that the landscape was covered continuously and rather thickly in fallout ash [Knuth and Thomae 2003]. Likewise, the rock-shelters along the River Leine preserve layers of primary air-fall tephra $<40 \mathrm{~cm}$ thick [Ahl and Meyer 1994]; of the nine rock-shelter sites with preserved LST (Abri Lustal II, Abri Stendel XVIII, Bettenroder Berg I, IX, XI, XIII, and XIV, Abri Schierenberg I, Abri Immengrund I), two (Bettenroder Berg I and IX) also preserve occupation layers from the Federmessergruppen.

The overall thickness of LST airfall deposits declines in the mid-field, following an exponential thinning pattern documented for other eruptions [Pyle 1989; Fisher and Schmincke 1984; Scasso et al. 1994; Bonadonna et al. 1998]. It is likely that loss of human life in the midfield as an immediate consequence of the LSE was lim- 


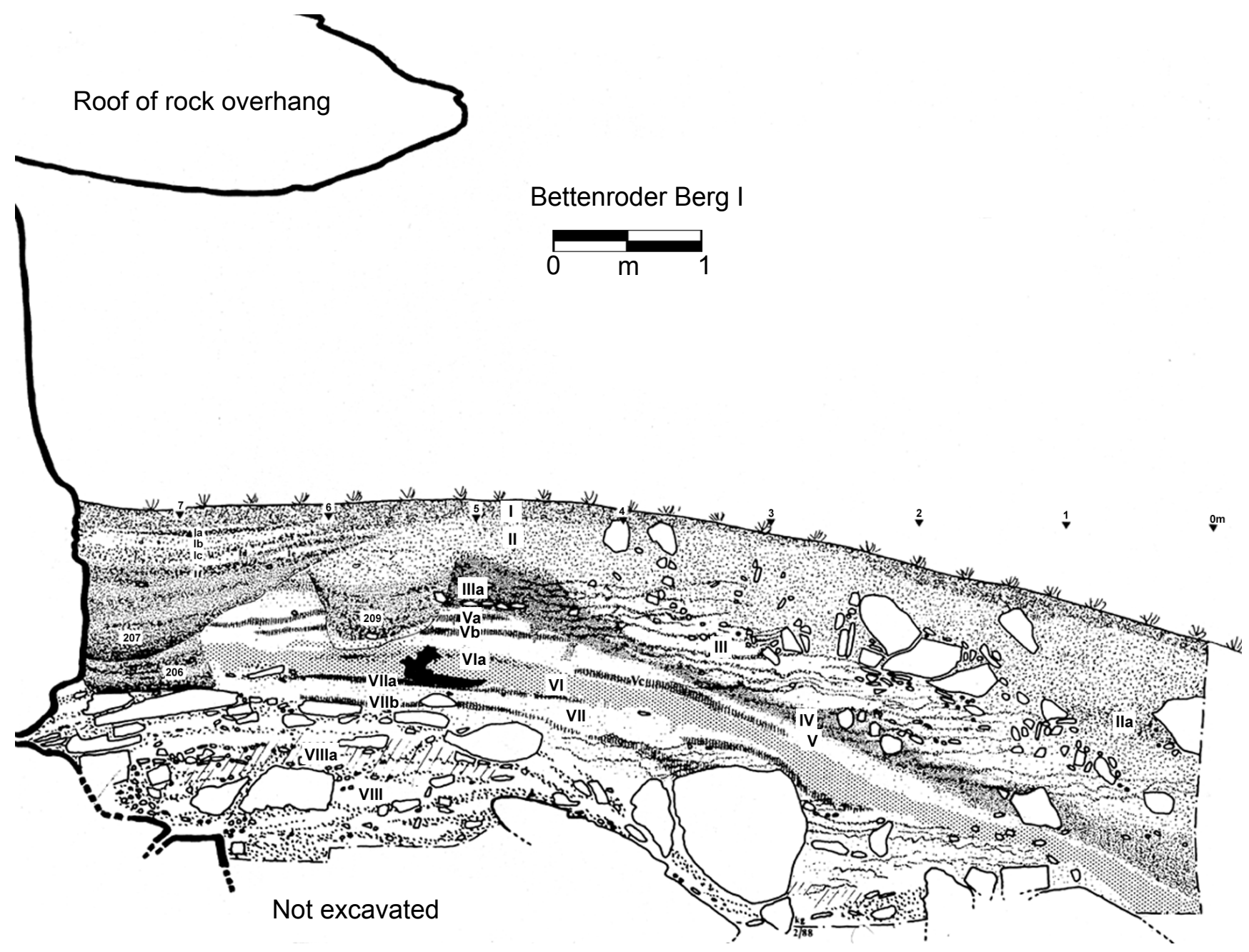

Figure 2: The stratigraphic sequence at Bettenroder Berg I. The ca. $2.5 \mathrm{~m}$ deep stratigraphy covers the period from just after the last glacial maximum (VIII) to the present (I). The bottom of the section is blocked by roofcollapse boulders; bedrock was not reached. Layer VIIa = Federmessergruppen occupation; layer VI = Laacher See tephra. Adapted from Grote [1994].

ited. However, the negative impacts on resources and livelihoods would have been substantial. Here we focus on the effects of airfall tephra; whether volcanic gases were important at mid-distances from the vent is unknown, and it is unclear whether subsequent climatic effects were related to the LST eruption.

\section{Methods}

With four main attributes-human health, shelter, food and water supply-selected as the most relevant contributors to societal resilience pre- and post-eruption, we first need to establish the relative importance of each of these attributes. It is unlikely that any reasonable group of professional anthropologists, archaeologists, and/or disaster scientists would reach reasoned agreement on the relative importance of these attributes. In order to assess inter-observer variability, we adopt the view that all views (in this case, the views of the first two authors: Participants A and B) are of equal value

We use Thomas Saaty's 1980 Analytical Hierarchy Process as provided by $\mathrm{BPMSG}^{\dagger}$ to establish the relative importance of the four attributes, beginning with the assumption that the four attributes are of equal value, but then using individual responses to a series of comparative questions to estimate the relative importance of each attribute, keeping in mind the aim of the exercise - that is, to establish the post- eruption resilience of a small group of Federmessergruppen people located in the mid-field area of the tephra fallout.

Each of the four attributes is composed of a set of sub-attributes. For example, food supply, as indicated earlier comes from large animals, small animals and

${ }^{*}$ While Participants A and B discussed the importance of the four main attributes (and other potential attributes), all assessments of attributes and sub-attributes were done independently. We note that this methodology allows relative weights to also be applied to the opinions of the 'experts', but we have chosen to average their views here.

${ }^{\dagger}$ http://bpmsg.com/academic/ahp-hierarchy.php 
from plants, and each of these sources might be adversely affected to different degrees by the eruption. For example, water supply might be from a river, lake, or spring, where water from a spring is likely to be less affected by tephra fall than water from a lake. In setting sub-attributes it is important to limit the number considered; if too many are used, each can only contribute a small part to the analysis such that the big picture is lost in the detail, and the analysis becomes needlessly complicated. For example, water quality in the Pleistocene is probably little-affected by the surrounding geology. While tephra falls are normally acidic and may affect water quality [c.f. Frogner Kockum et al. 2006], we have chosen not to complicate the analysis by considering the buffering effect that a limestone/carbonate-rich geology might have on water quality post-eruption. Later we show how this and other qualifiers can be allowed for in the subsequent analysis.

In this study, the four attributes are divided into 13 sub-attributes. Each of these sub-attributes is also weighted by Participants A and B using the same BPMSG fuzzy logic program, again with the total value ascribed to all attributes summing to 1.0. We then determined how a fall of volcanic ash would affect the 'value' of each of these attributes, or at least of those deemed to be most important to the resilience of the Federmessergruppen. We have done this by developing a series of 'loss curves' that relate the loss in 'value' to the thickness of the volcanic ash that fell at the site under consideration. Figure 3 illustrates the methodology, in this case applied to the vulnerability of small mammals to thicknesses of tephra fall ranging from 0 to $20 \mathrm{~cm}$. Throughout, the tephra fall thicknesses used are compacted thicknesses which, we assume, are about half the freshly-fallen tephra thicknesses [Blong et al. 2017a].

For many natural hazards, such as hurricanes, earthquakes, floods and hailstorms, the vulnerability of physical assets such as buildings to the event have been well-modelled by global companies such as Risk Management Solutions (RMS) and Applied Insurance Research (AIR) as well as a host of other smaller providers and academic institutions. However, these loss model providers have rarely produced loss curves for volcanic eruptions and not at all for any of the attributes with which we are concerned.

Both of the first two authors have been interested in the impact of volcanic eruptions on people and environments for many years [Blong 1982; Blong 1984; Blong 2000; Riede 2014b; Riede 2014c; Riede 2015; Riede 2016]. For each of the important attributes we have scoured the literature and assessed the positive and negative effects of the characteristics of ash falls and on the character of the attribute under consideration. Some of the relevant details are set out in Appendix A. For example, for the small animals likely to be a food source for the Federmessergruppen, we have examined factors such as the particle size of the tephra, the habitat of the animals (arboreal, ground-dwelling or fossorial [below ground-dwelling], carnivorous, herbivorous, or omnivorous), some animal characteristics relating to tooth abrasion and skin/fur irritation, and post-eruption conditions relating to seasonality of the eruption, rainfall and windiness (the latter two influencing post-eruption remobilisation of the ash).

Several points arise from this analysis: (i) there are many confounding factors; (ii) there is considerable scope for double-counting of the consequences; (iii) curves such as those in Figure 3 apply summarily to a number of different species of small animals; and (iv) we have had to rely inordinately on our judgement. With these issues in mind, we have provided a 'high' and a 'low' value for each vulnerability curve. The high and low values should not be regarded as representing a standard deviation from a mean value, or even as limits on vulnerability for a specific tephra thickness; they merely represent our view of the likely range in variation. With more information and/or with specific cases in mind the assessment of a particular vulnerability can be adjusted within the range provided, a mean value can be used, or assessments outside the limits suggested by the high and low curves are certainly acceptable. This latter point is evident from Appendix A where several of our Federmessergruppenspecific judgements lie outside the high and low envelope.

In order to simplify the analysis, we have amalgamated the 13 sub-attributes into six fields which not only capture the important weights and variations in Table 2 but also make full use of the data available to us about the Federmessergruppen lifestyle and ecosystem. The four health attributes have been combined into a single field which we have characterised as "health" for which we have ascribed high, medial, and low vulnerability curves (Appendix A). Similarly, we have reduced shelter to two fields; we do not have sufficient data to differentiate between the protection offered by rock overhangs and caves respectively. Thus, in Appendix A we establish separate high and low curves for (i) tent-like structures and for (ii) rock overhangs and caves.

We have developed distinctive high and low vulnerability curves for each of the three main food sources (large animals, small animals, and plants) as set out in Table 2. As Appendix A records, we have developed these curves with our understanding of the specific Federmessergruppen environment in mind. We emphasise that we could develop different vulnerability curves for differing environments. For example, we have chosen to focus only on plants growing reasonably close to the ground although, following the MIAVITA guidelines [Bignami et al. 2012], we have developed vulnerability curves for five reasonably distinctive plant growth forms/ food sources; here we show the curves for the group—small herbaceous plants and 


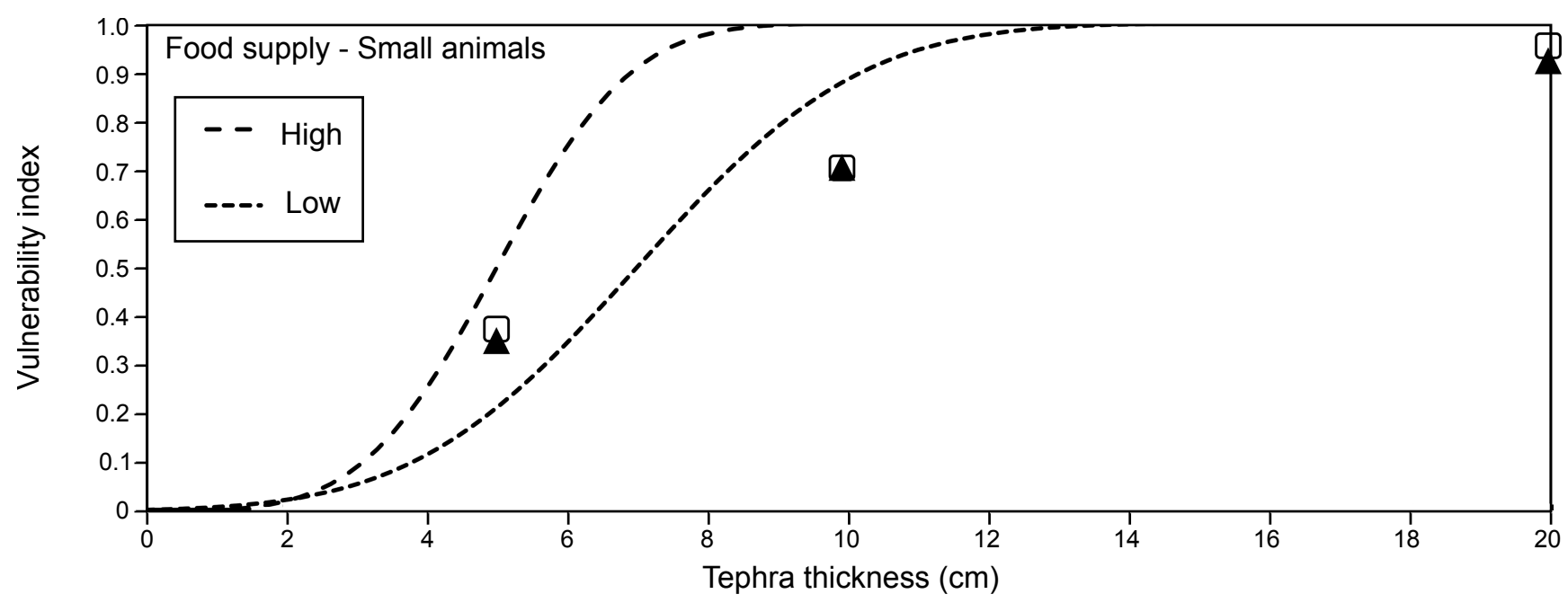

Figure 3: 'High' and 'low' vulnerability curves illustrating the likely effects of tephra falls of between 0.1 and $20 \mathrm{~cm}$ (compacted thickness) on small animals. These curves are general vulnerability curves for small animals; 'high' and 'low' views may differ for specific animals or where the tephra fall has particular characteristics. See further explanation in the text. The squares represent the views of Participant A, the triangles the views of Participant B.

creepers-that we believe were the most likely plant food source for Federmessergruppen people. As we have very limited information about the water sources used by the FMG and sparse details on the potential differences in the effects of the LST on Springs and Lakes we have developed just a pair of high and low curves for water supply.

At this point then, we have six vulnerability curves for four attributes, all expressed in terms of vulnerability on a scale of $0-1.0$ (see Appendix A):

- Health: expressed as the proportion of the population killed with high, low and medial rates;

- Shelter: high and low curves for (i) tent-like structures and (ii) caves and rock overhangs;

- Plants: high and low curves for small herbaceous plants and creepers;

- Small animals: high and low curves; see Figure 3;

- Large animals: high and low curves;

- Water supply: high and low curves.

Thus, the 13 sub-attributes used in the fuzzy logic estimates of importance to the Federmessergruppen community resilience near Bettenroder Berg are represented in six sets of vulnerability curves, each using the range of $0-20 \mathrm{~cm}$ (compacted) ash fall thickness. We have selected tephra fall thicknesses of 5, 10 and $20 \mathrm{~cm}$ to provide a range of vulnerabilities. For example, if Participant A assumes from Figure 3 that the vulnerability for small animals to a $5 \mathrm{~cm}$ thick tephra fall is 0.5 and the attribute weight for the small animal contribution to Federmessergruppen resilience is 0.1 (i.e. $10 \%$ ), then the contribution to the reduction in resilience (i.e. vulnerability) as a result of the ash fall is 0.05 . The six contributions representing the 13 subattributes are then summed to produce the total reduction in resilience as a result of the $5 \mathrm{~cm}$ thick ash fall.

\section{Results}

Table 1 shows the relative weights (\%) for Participants $\mathrm{A}$ and $\mathrm{B}$ and the averaged response of the two participants. In each case the weightings sum to $100 \%$. Participant A rates food supply significantly more highly than Participant B, but the reverse is true for water supply. Nonetheless both participants agree that food and water supplies are much more important to FMG resilience than human health and shelter.

Participants $\mathrm{A}$ and $\mathrm{B}$ also provided relative weights (\%) for each of the 13 sub-attributes using the BPMSG AHP program (Table 2). Effectively these weightings create for each participant the relative contributions to the post-eruption resilience of the Federmessergruppen in the mid-field are where tephra falls are moderate (5$20 \mathrm{~cm}$ in compacted thickness). We have also averaged the responses of $\mathrm{A}$ and $\mathrm{B}$ to provide a combined response. Given the methodology, the two participants could have chosen differing sub-attributes, but that would have made our views of pre- and post-eruption resilience more problematic, so we kept to the one set.

Table 3 shows the weights provided by participants A and B (Columns A Wt and B Wt respectively) for the six selected fields, the relative vulnerabilities for each of the six fields estimated by each participant (A Vuln and B Vuln respectively) and the contribution of each of the six fields to the total vulnerability (Columns A $\mathrm{Wt} / 100 \times \mathrm{A}$ Vuln and B Wt/100 $\times \mathrm{B}$ Vuln respectively), for each of the three tephra fall thicknesses considered 
Table 1 - The relative weights (\%) given to each of the four main attributes for Participants A (RB) and B (FR) and the averaged response of the two participants.

\begin{tabular}{rccc}
\hline Attribute & Participant A & Participant B & Combined response \\
\hline Health & 8.8 & 4.6 & 6.7 \\
Shelter & 15.7 & 15.9 & 5.8 \\
Food supply & 48.3 & 33.0 & 40.65 \\
Water supply & 27.2 & 46.6 & 36.9 \\
\hline Total & 100.0 & 100.1 & 100.05 \\
\hline
\end{tabular}

Table 2 - The weights (\%) given to each of the 13 resilience sub-attributes by Participants A and B using the BPMSG AHP program.

\begin{tabular}{rcccc}
\hline Attribute & Sub-attribute & Response A & Response B & Combined response \\
\hline \multirow{5}{*}{ Health } & Physical health & 1.7 & 1.0 & 1.35 \\
& Mental health & 1.0 & 0.5 & 0.75 \\
& Nutritional status & 4.2 & 2.6 & 3.4 \\
& Disease/Infection & 1.9 & 0.6 & 1.25 \\
\cline { 2 - 5 } Shelter & Tent-like structures & 9.9 & 12.1 & 11.0 \\
& Rock overhangs & 2.4 & 2.9 & 2.65 \\
& Caves & 3.4 & 0.8 & 2.1 \\
\cline { 2 - 5 } Food supply & Large animals & 26.4 & 25.3 & 25.85 \\
& Small animals & 12.7 & 2.5 & 7.6 \\
& Plants & 9.2 & 5.2 & 7.2 \\
\cline { 2 - 5 } Water supply & River/stream & 17.0 & 21.2 & 19.1 \\
& Lake & 6.5 & 21.2 & 13.85 \\
& Spring & 3.7 & 4.2 & 3.95 \\
\hline Total & & 100.0 & 100.1 & 100.05 \\
\hline
\end{tabular}

here $(5,10$ and $20 \mathrm{~cm})$. Combined values are shown in Table 2. The vulnerability values chosen by A and $\mathrm{B}$ are also shown on each of the six vulnerability curve diagrams in Appendix A.

The results shown numerically in Table 3 are further summarised in Figure 4 together with the combined view of the two participants. However, Figure 4 shows these results expressed as resilience; that is as $1-$ Vulnerability. While it is not straightforward to interpret the meaning of these resilience scores, Figure 4 reinforces the impression that participants $\mathrm{A}$ and $\mathrm{B}$ are in good agreement; the Federmessergruppen community would very likely survive a tephra fall of $5 \mathrm{~cm}$ with a reduction of about $20 \%$ in their resilience. Similarly, $\mathrm{A}$ and $\mathrm{B}$ agree that the resilience of the Federmessergruppen would be reduced by about $80 \%$ by a tephra fall of $20 \mathrm{~cm}$.

\section{Discussion}

While Figure 4 indicates that Participants A and B are in good agreement about the resilience of the Federmessergruppen community to tephra fall, this summary result averages some difference in views. Ta- ble 1 summarises the attribute weightings arrived at independently by Participant A and Participant B. Figure 5 shows the contributions to vulnerability from the six short-listed fields. Water supply is the biggest differentiator between the two participants' views, although there are also divergent views on the importance of small animals to food supply. Rather surprisingly, neither participant saw the health component as being a particularly significant contributor to the overall vulnerability, although Participants A and B judged health to have vulnerabilities of $35 \%$ and $20 \%$, respectively, in the case of a $20 \mathrm{~cm}$ tephra fall (see Table 3). The differences in views are even more pronounced in relation to judgements made about the effects of a $5 \mathrm{~cm}$ tephra fall (Figure 6). As Participants $\mathrm{A}$ and B completed their assessments independently, we do not know whether these differences reflect variations in experience, knowledge of the literature, training, or imagination. Indeed, if the aim is to generate consensus, then the methodology's agnostic treatment of difference is a strength.

Given these divergent views regarding the contribution of individual components of vulnerability it is interesting that the final vulnerability scores are quite 
Table 3 - The weights (\%) given to each of the 13 resilience sub-attributes by Participants A and B using the BPMSG AHP program.

\begin{tabular}{rcccccc}
\hline Sub-attribute & A Wt & A Vuln & A Wt $/ 100 \times$ A Vuln & B Wt & B Vuln & B Wt/100 $\times$ B Vuln \\
\hline Health & 8.8 & 0.35 & 0.031 & 4.7 & 0.20 & 0.009 \\
Shelter & 15.7 & 0.98 & 0.154 & 15.8 & 0.98 & 0.155 \\
Plants & 9.2 & 0.99 & 0.091 & 5.2 & 0.90 & 0.047 \\
Small animals & 12.7 & 0.95 & 0.121 & 2.5 & 0.90 & 0.023 \\
Large animals & 26.4 & 0.85 & 0.224 & 25.3 & 0.90 & 0.228 \\
Water supply & 27.2 & 0.65 & 0.177 & 46.6 & 0.80 & 0.373 \\
\hline Total & 100.0 & - & 0.798 & 100.1 & - & 0.834 \\
\hline & \multicolumn{7}{c}{10 cm-thick tephra fall } \\
\hline Health & 8.8 & 0.10 & 0.009 & 4.70 & 0.08 & 0.004 \\
Shelter & 15.7 & 0.73 & 0.115 & 15.8 & 0.80 & 0.126 \\
Plants & 9.2 & 0.95 & 0.087 & 5.2 & 0.70 & 0.036 \\
Small animals & 12.7 & 0.70 & 0.089 & 2.5 & 0.70 & 0.018 \\
Large animals & 26.4 & 0.45 & 0.119 & 25.3 & 0.30 & 0.076 \\
Water supply & 27.2 & 0.30 & 0.082 & 46.6 & 0.40 & 0.186 \\
\hline Total & 100.0 & - & 0.500 & 100.1 & - & 0.446 \\
\hline & \multicolumn{7}{c}{5 cm-thick tephra fall } \\
\hline Health & 8.8 & 0.05 & 0.004 & 4.7 & 0.05 & 0.002 \\
Shelter & 15.7 & 0.18 & 0.028 & 15.8 & 0.30 & 0.047 \\
Plants & 9.2 & 0.55 & 0.051 & 5.2 & 0.40 & 0.021 \\
Small animals & 12.7 & 0.35 & 0.044 & 2.5 & 0.30 & 0.008 \\
Large animals & 26.4 & 0.25 & 0.066 & 25.3 & 0.10 & 0.025 \\
Water supply & 27.2 & 0.18 & 0.049 & 46.6 & 0.20 & 0.093 \\
\hline Total & 100.0 & - & 0.243 & 100.1 \\
\hline
\end{tabular}

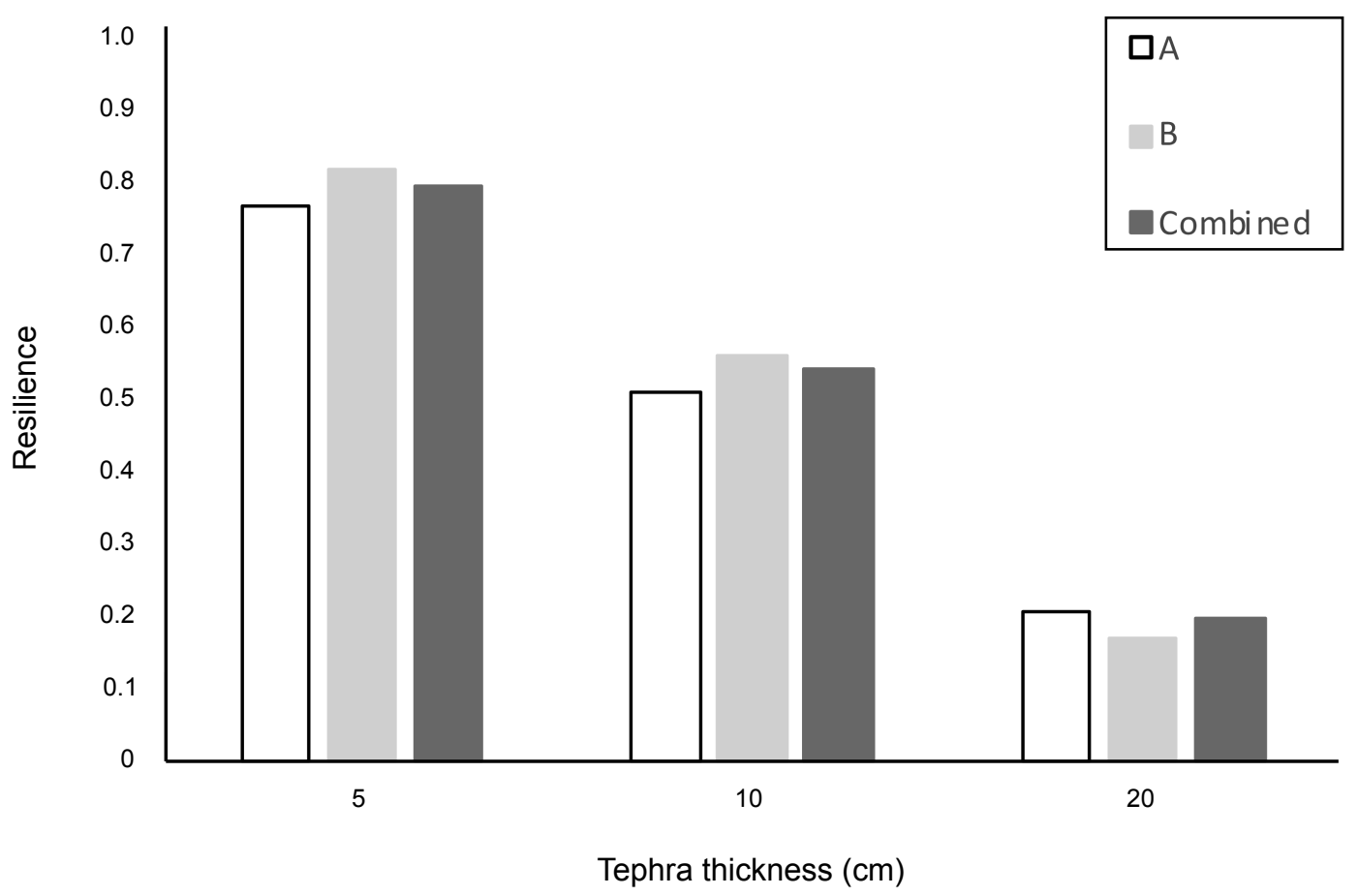

Figure 4: Resilience ( $R=1-$ Vulnerability) of Palaeolithic foragers in Europe to Laacher See tephra fall thicknesses of 5,10 , and $20 \mathrm{~cm}$, estimated by independent expert assessments. 


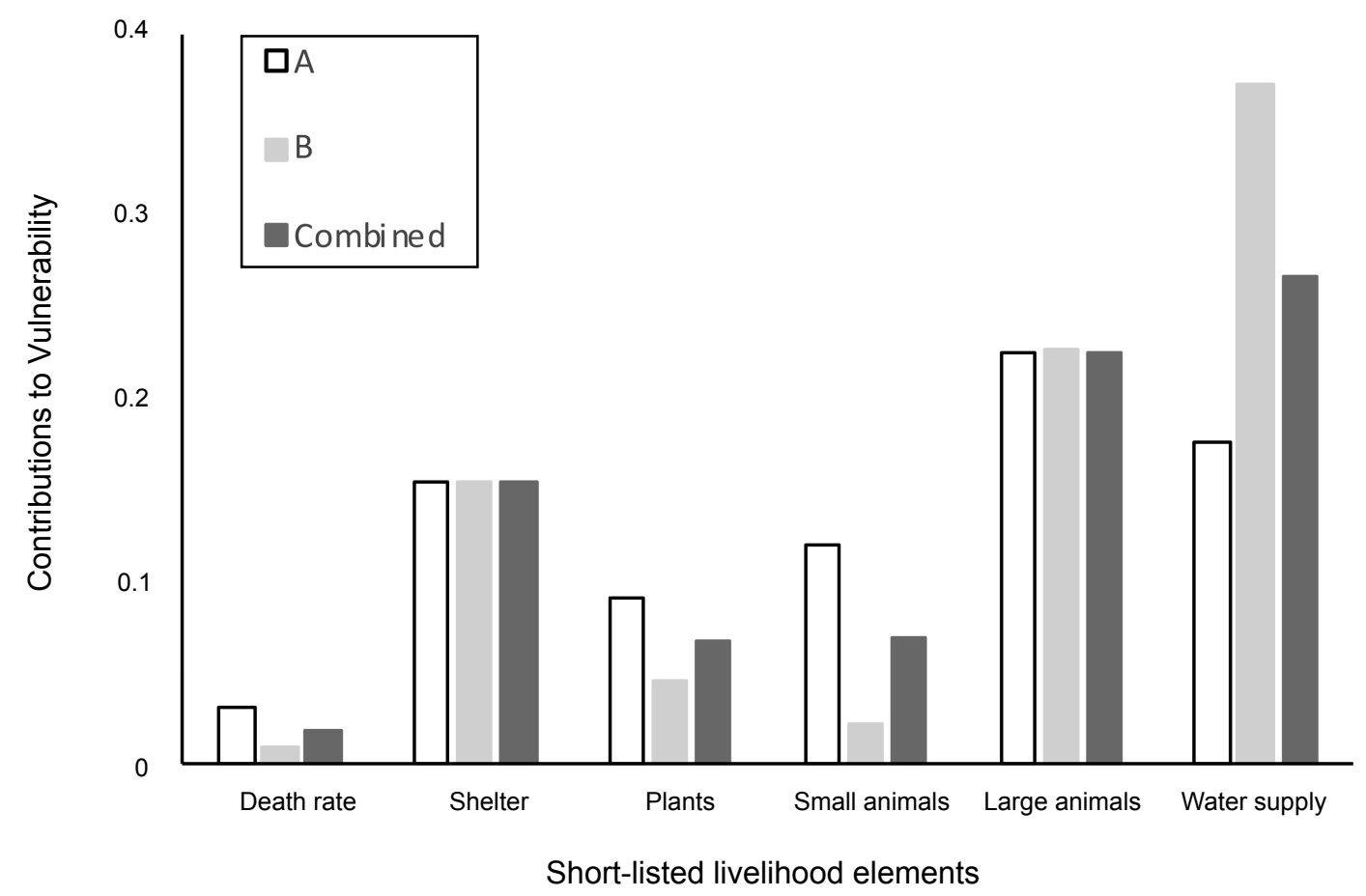

Figure 5: Participant A and B and combined contributions to vulnerability from the six short-listed fields for 20 $\mathrm{cm}$ tephra fall.

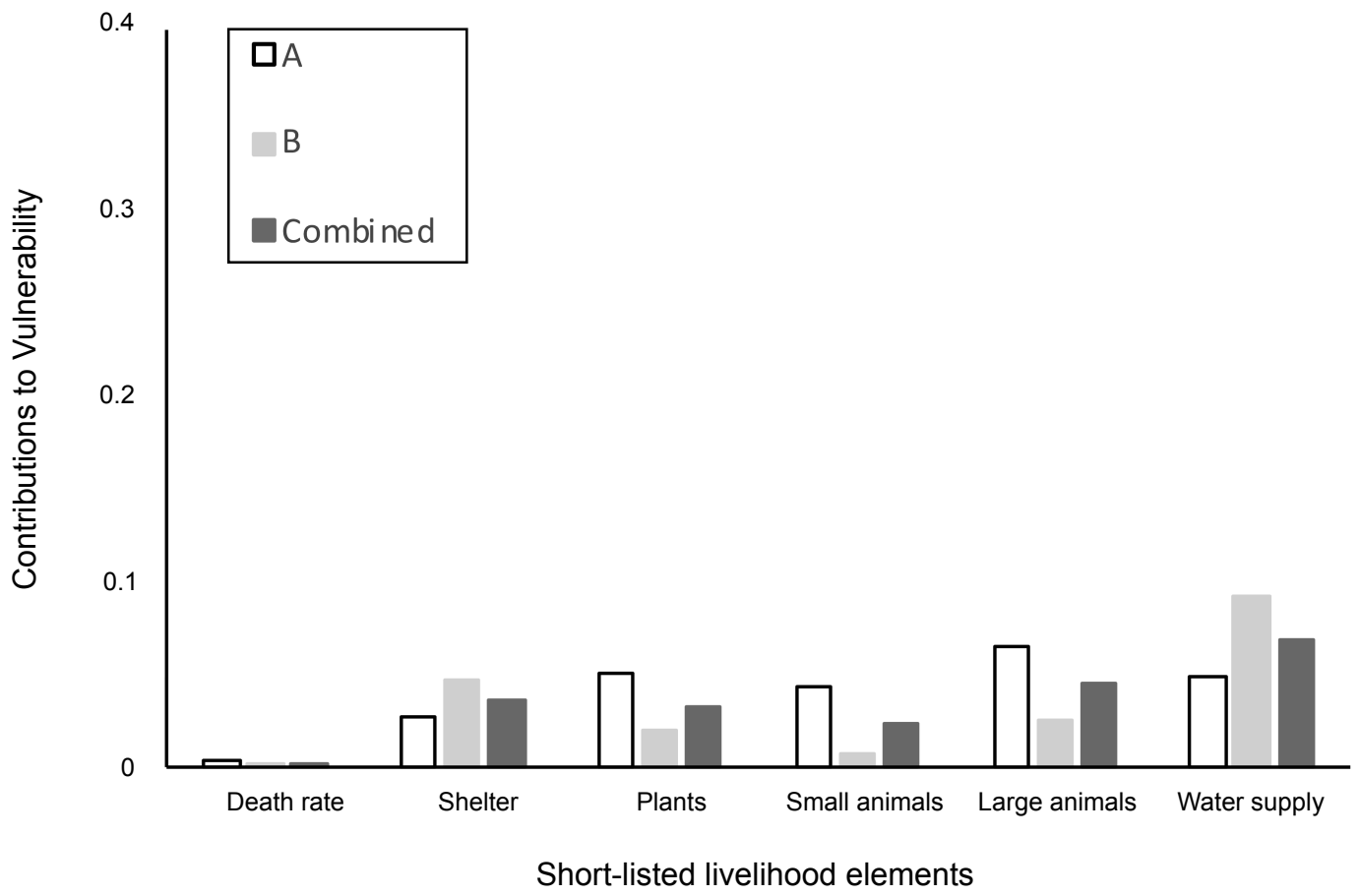

Figure 6: Participant A and B and combined contributions to vulnerability from the six short-listed fields for 5 cm tephra fall.

similar $(0.24$ and 0.20 in the case of a $5 \mathrm{~cm}$ tephra fall, Participant A and B respectively). Similarly, Figure 7 compares four sets of contributions to total vulnerability for the three thicknesses of LST tephra. The left-hand columns for each tephra thickness show con- tributions to vulnerability using the high vulnerability curves for each of the six fields in Appendix A while the right-hand columns summarise contributions using the low vulnerability curves. The intermediate columns show the contributions assessed by Participants A and 
B. Thus, while individual assessments differ significantly in relation to some fields, the differences in details average out across categories. In all cases but one, the sums of Participant A and B's assessments lie between those derived from the vulnerability curves. Only for the $5 \mathrm{~cm}$ tephra fall Participant A's estimates sum to 0.24 whereas the high vulnerability curves sum to 0.23 .

Full agreement is not a necessary condition of the methodology and divergent views could be exaggerated rather than averaged in some analyses. Although A's and B's expertise was judged equal in the present analysis we cannot be certain that that is a reasonable assumption. In future analyses of this type it would be wise to include the views of many more participants although it is clearly necessary to use some form of expert elicitation to assess the expertise of the experts [Aspinall 2010; Aspinall and Cooke 2013].

In this semi-quantiative account we have used fuzzy logic and professional judgement or selective heuristics to arrive at a view of the vulnerability (and as defined here, the inverse, resilience) of a small group of people in a specific environment to a fall of volcanic ash. Clearly, we could have employed more attributes dealing with specific food sources, a detailed understanding of the physical landscape, or a nuanced understanding of the grain size of the tephra or its likely chemical load. We have not done this because there are too many factors involved and too many confounding lines of information where we cannot readily capture causal contributions. However, we have allowed for possible increases in knowledge by setting rather arbitrary boundaries with maximum and minimum vulnerability curves; in some cases (see Appendix A) we have stepped outside these boundaries ourselves. A vulnerability value might be assigned near the maximum curve because the participant judged the combination of fine particle size and chemical load meant that water supply might be more compromised than normally. Or that the omnivorous eating habits of an important animal food source and the animals' willingness to modify its diet suggests that this particular species will survive a tephra fall more readily than others.

These issues are all matters of qualified judgement. While different users will make different judgements about many aspects of vulnerability or resilience, the methodology employed here has the advantage that it forces users to think reasonably clearly and along a moderately well-defined pathway about which aspects of tephra fall are important and how significant they are to the issue at hand. We would be hard pushed to argue that a Federmessergruppen community near the Bettenroder Berg experienced exactly an $80 \%$ decline in resilience with a fall of $20 \mathrm{~cm}$ of Laacher See tephra 13,000 years ago; but we are more confident that the decline in resilience compared with groups that experienced 10 and $5 \mathrm{~cm}$ falls of ash is about right, given that all the physical, social, cultural, and ecological frame- works remain constant.

If we were to broaden the comparison in resilience to, for example, make comparisons with more northerly groups of Palaeolithic foragers where the resource base was narrower, the climate more volatile, and the arrival of spring later, we would need to revisit the attribute weightings we used. Similarly, our investigation examined resilience in the immediate aftermath of the Laacher See eruption and tephra fall, extending only one to two years after the eruption. We have assumed that the initial ash deposit was probably twice the compacted thickness we have used in all our assessments and that compaction would have occurred within a few days, particularly if it rained. We have not allowed for remobilisation and redeposition, which might have thinned the ash on steeper slopes possibly allowing more rapid recovery of vegetation and fodder at the same time as it produced thicker ash deposits on more favoured lower-lying areas alongside streams. Considerations such as these indicate that it is particularly important to have a clear vision of the aims of the analysis as they may affect the weightings given to particular attributes as well as modify the vulnerability and resilience assesments.

\section{Conclusions}

A large and ever increasing number of people live in areas under direct threat from volcanic eruptions [Chester et al. 2001]. The number of well-studied recent eruptions on which to base robust estimations of the impact on humans and their communities remains small, however. Here, past eruptions and their societal consequences as documented in historical or archaeological archives offer the opportunity to significantly broaden our evidence base both in terms of eruption types and in terms of the types of societies affected [Sheets 2012; Riede 2014b]. Such past case studies can help us with "imagining the unimaginable" [Donovan and Oppenheimer 2018] and, hence, be better able to prepare for it [Clarke 2008a; Clarke 2008b; Riede 2017a].

Yet, investigations of past volcanism and its human consequences face a double conundrum: both eruptions and the societies they affect are unique in many if not most regards [c.f. Cashman and Biggs 2014]. Our study attempts to contribute to a more systematic and explicit assessment of vulnerability and resilience in case studies with low data availability. Such limited data availability is characteristic of many ancient eruptions where geological signatures need to be paired with historical or archaeological data. Limited data availability may also characterise contemporaneous events in remote areas and in relation to poorlystudied volcanic systems.

Finally, our study offers a methodology for evaluating and integrating inter-observer variability in as- 

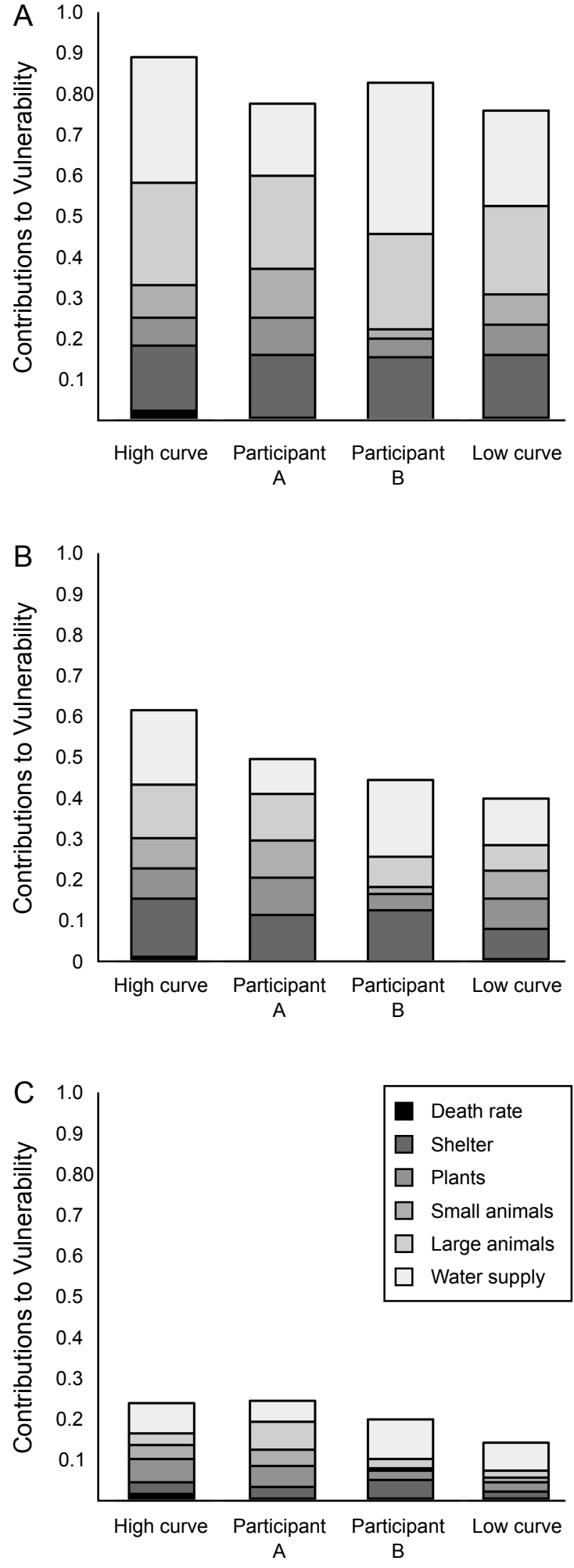

Figure 7: The contributions to vulnerability from the six fields for [A] $20 \mathrm{~cm}$ of LST; [B] $10 \mathrm{~cm}$ LST; and [C] $5 \mathrm{~cm}$ of tephra. Left-hand columns use the high vulnerability curves shown for each of the six fields in Appendix A; right-hand columns use the low vulnerability curves, while the two central columns indicate the contributions assessed by Participants A and B. sessing these vulnerability factors, which offers important ways forward not only for capturing uncertainty in expert judgements, but also for conjoining the many disciplines and stakeholders involved in volcanology and volcanic risk assessment [Fuchs et al. 2012]. Numerous studies have called for greater integration of the natural and social/historical sciences in assessing past and present vulnerability and resilience to environmental change and events [e.g. Caseldine and Turney 2010; Izdebski et al. 2016], but realising such interdisciplinarity remains challenging. The methodology we have presented here may assist in building bridges between different fields concerned with human impacts of extreme environmental events and changes. Uncertainty is part and parcel of the scientific process, but need not be seen as weakness [Oreskes 2015]. We are confident that our methodology could be readily adapted to other case studies of ancient and not-soancient volcanism or other hazards and their human impact.

\section{ACKnowledgements}

This work has been funded by the Danish Council for Independent Research Sapere Aude grant 6107-00059B (Apocalypse then? The Laacher See volcanic eruption (13,000 years before present), Deep Environmental History and Europe's geo-cultural heritage). We thank Florian Sauer for his assistance with Figure 1 and the two anonymous reviewers for the thorough reading of our manuscript.

\section{Author CONTRibutions}

The project was conceived by RB and FR. The spreadsheets and methodology for estimating vulnerability/ resilience were designed by RB and built by QYC; FR generated all figures. All authors contributed to the writing of the paper.

\section{Data AVAilability}

All necessary data are included in Appendix A.

\section{COPYRIGHT NOTICE}

(c) The Author(s) 2018. This article is distributed under the terms of the Creative Commons Attribution 4.0 International License, which permits unrestricted use, distribution, and reproduction in any medium, provided you give appropriate credit to the original author(s) and the source, provide a link to the Creative Commons license, and indicate if changes were made. 


\section{REFERENCES}

Adger, W. N. (2006). "Vulnerability". Global Environmental Change 16.3, pp. 268-281. Dor: $10.1016 / \mathrm{j}$. gloenvcha.2006.02.006.

Ahl, C. and B. Meyer (1994). "Zur bodenkundlichsedimentologischen Horizontabfolge der Hauptabris im Buntsandsteingebiet von Reinhausen". Die Abris im südlichen Leinebergland bei Göttingen. Archäologische Befunde zum Leben unter Felsschutzdächern in urgeschichtlicher Zeit. Isensee Verlag, Oldenburg, pp. 37-52.

Andersen, D. C. (1982). "Observations on Thomomys talpoides in the Region Affected by the Eruption of Mount St. Helens". Journal of Mammalogy 63.4, pp. 652-654. DoI: 10.2307/1380271.

Andersen, D. C. and J. A. MacMahon (1985). "The Effects of Catastrophic Ecosystem Disturbance: The Residual Mammals at Mount St. Helens". Journal of Mammalogy 66.3, pp. 581-589. DoI: 10 . 2307 / 1380942.

Antos, J. A. and D. B. Zobel (1982). "Snowpack Modification of Volcanic Tephra Effects on Forest Understory Plants Near Mount St. Helens". Ecology 63.6, p. 1969 . DoI: $10.2307 / 1940135$.

Arnalds, O. (2013). "The Influence of Volcanic Tephra (Ash) on Ecosystems". Advances in Agronomy. Ed. by D. L. Sparks. Elsevier, pp. 331-380. Dor: 10.1016/ b978-0-12-407685-3.00006-2.

Aspinall, W. (2010). "A route to more tractable expert advice”. Nature 463.7279, pp. 294-295. DoI: 10. 1038/463294a.

Aspinall, W. and R. Cooke (2013). "Quantifying scientific uncertainty from expert judgement elicitation". Risk and uncertainty assessment for natural hazards. Ed. by J. Rougier, S. Sparks, and L. Hill. Cambridge University Press Cambridge, UK, p. 64.

Baales, M. and M. Street (1999). "Late Glacial Federmessergruppen in the Central Rhineland". L'Europe des derniers chasseurs: Épipaléolithique et Mésolithique. Ed. by A. Thévenin and P. Bintz. Vol. 5. Comité des travaux historiques et scientifiques-CTHS, pp. 225235.

Baales, M. (2002). "Vulkanismus und Archäologie des Eiszeitalters am Mittelrhein. Die Forschungsergebnisse der letzten dreissig Jahre". Jahrbuch des Römisch-Germanischen Zentralmuseums Mainz 49, pp. 43-80. DoI: 10.11588/ jrgzm.2002.0.23282.

Baales, M., O. Jöris, M. Street, F. Bittmann, B. Weninger, and J. Wiethold (2002). "Impact of the Late Glacial Eruption of the Laacher See Volcano, Central Rhineland, Germany". Quaternary Research 58.03, pp. 273-288. Dor: 10.1006/qres.2002.2379.

Ballari, S. A. and M. N. Barrios-Garcia (2013). "A review of wild boarSus scrofadiet and factors affecting food selection in native and introduced ranges". Mammal Review 44.2, pp. 124-134. Dor: $10.1111 /$ mam. 12015.
Bignami, C., V. Bosi, L. Costantini, C. Cristiani, F. Lavigne, and P. Thierry (2012). "Handbook for volcanic risk management: Prevention, crisis management and resilience". Handbook for volcanic risk management: Prevention, crisis management and resilience. Ed. by C. Bignami, V. Bosi, L. Costantini, C. Cristiani, F. Lavigne, and P. Thierry. MiaVita. Bureau de Recherches Géologiques et Minières.

Birkmann, J., O. D. Cardona, M. L. Carreño, A. H. Barbat, M. Pelling, S. Schneiderbauer, S. Kienberger, M. Keiler, D. Alexander, P. Zeil, and T. Welle (2013). "Framing vulnerability, risk and societal responses: the MOVE framework". Natural Hazards 67.2, pp. 193-211. DoI: 10.1007/s11069-013-0558-5.

Blackford, J. J., K. J. Edwards, A. J. Dugmore, G. T. Cook, and P. C. Buckland (1992). "Icelandic volcanic ash and the mid- Holocene Scots pine (Pinus sylvestris) pollen decline in northern Scotland". The Holocene 2.3, pp. 260-265. Dor: 10 . 1177 / 095968369200200308.

Blong, R. J., P. Grasso, S. F. Jenkins, C. R. Magill, T. M. Wilson, K. McMullan, and J. Kandlbauer (2017b). "Estimating building vulnerability to volcanic ash fall for insurance and other purposes". Journal of Applied Volcanology 6.1. DoI: 10.1186/s13617-0170054-9.

Blong, R. J. (1982). The time of darkness: local legends and volcanic reality in Papua New Guinea. Canberra: Australian National University Press.

- (1984). Volcanic hazards: a sourcebook on the effects of eruptions. Sydney: Academic Press.

- (2000). "Volcanic Hazards and Risk Management". Encyclopaedia of Volcanoes. Ed. by H. Sigurdsson, B. Houghton, S. McNutt, H. Rymer, and J. Stix. San Diego, USA: Academic Press, pp. 1215-1227.

- (2003). "Building damage in Rabaul, Papua New Guinea, 1994". Bulletin of Volcanology 65.1, pp. 4354. DoI: 10.1007 / s00445-002-0238-x.

Blong, R. J., N. Enright, and P. Grasso (2017a). "Preservation of thin tephra". Journal of Applied Volcanology 6.1. DoI: $10.1186 / \mathrm{s} 13617-017-0059-4$.

Bonadonna, C., G. Ernst, and R. Sparks (1998). "Thickness variations and volume estimates of tephra fall deposits: the importance of particle Reynolds number". Journal of Volcanology and Geothermal Research 81.3-4, pp. 173-187. Dor: 10.1016/s0377-0273 (98) 00007-9.

Bradtmöller, M., S. Grimm, and J. Riel-Salvatore (2017). "Resilience theory in archaeological practice - An annotated review". Quaternary International 446, pp. 316. DoI: 10.1016/ j .quaint.2016.10.002.

Bratlund, B. (1993). "Ein Riesenhirschschädel mit Bearbeitungsspuren aus Lüdersdorf, Kreis Grevesmühlen”. Offa 49.50, pp. 7-14.

Büntgen, U. et al. (2016). "Cooling and societal change during the Late Antique Little Ice Age from 536 to around 660 AD". Nature Geoscience 9.3, pp. 231-236. DoI: $10.1038 /$ ngeo2652. 
Burt, W. H. (1961). "Some effects of Volcán Parícutin on vertebrates". Occasional papers of the Museum of Zoology, University of Michigan, pp. 1-22.

Caseldine, C. J. and C. Turney (2010). "The bigger picture: towards integrating palaeoclimate and environmental data with a history of societal change". Journal of Quaternary Science 25.1, pp. 88-93. Dor: 10 . 1002 / jqs. 1337.

Cashman, K. and J. Biggs (2014). "Common processes at unique volcanoes-a volcanological conundrum". Frontiers in Earth Science 2. DoI: 10.3389 / feart . 2014.00028.

Charles, R. (1997). "The Exploitation of Carnivores and Other Fur-bearing Mammals during the Northwestern European Late and Upper Paleolithic and Mesolithic". Oxford Journal of Archaeology 16.3, pp. 253-277. Dor: 10.1111/1468-0092.00040.

Chester, D., M. Degg, A. Duncan, and J. Guest (2001). "The increasing exposure of cities to the effects of volcanic eruptions: a global survey". Global Environmental Change Part B: Environmental Hazards 2.3, pp. 89-103. DoI: 10.1016/s1464-2867 (01) 00004-3.

Clarke, L. (2008a). "Possibilistic thinking: a new conceptual tool for thinking about extreme events". social research, pp. 669-690.

- (2008b). "Thinking about Worst-Case Thinking". Sociological Inquiry 78.2, pp. 154-161. DoI: 10.1111/ j . 1475-682x.2008.00230.x.

Cooper, J. and P. D. Sheets, eds. (2012). Surviving sudden environmental change: answers from archaeology. Boulder, CO: University of Colorado Press.

Crisafulli, C. M., F. J. Swanson, J. J. Halvorson, and B. D. Clarkson (2015). "Volcano ecology: disturbance characteristics and assembly of biological communities". The Encyclopedia of Volcanoes (Second Edition). Ed. by H. Sigurdsson. Elsevier, pp. 1265-1284.

Cronin, S. J., V. Manoharan, M. J. Hedley, and P. Loganathan (2000). "Fluoride: A review of its fate, bioavailability, and risks of fluorosis in grazedpasture systems in New Zealand". New Zealand Journal of Agricultural Research 43.3, pp. 295-321. DoI: 10.1080/00288233.2000.9513430.

Cutter, S. L., B. J. Boruff, and W. L. Shirley (2003). "Social Vulnerability to Environmental Hazards". Social Science Quarterly 84.2, pp. 242-261. DoI: $10.1111 /$ $1540-6237.8402002$.

d'Errico, F. and W. E. Banks (2015). "Tephra studies and the reconstruction of Middle-to-Upper Paleolithic cultural trajectories". Quaternary Science Reviews 118, pp. 182-193. Dor: 10.1016/ j . quascirev . 2014.05 .014

Dale, V. H., J. Delgado-Acevedo, and J. MacMahon (2005). "Effects of modern volcanic eruptions on vegetation". Volcanoes and the Environment. Ed. by J. Martí and G. G. J. Ernst. Cambridge University Press Cambridge, pp. 227-249.

Davies, T. et al. (2015). "Towards disaster resilience: A scenario-based approach to co-producing and in- tegrating hazard and risk knowledge". International Journal of Disaster Risk Reduction 13, pp. 242-247. Dor: 10.1016/ j.i jdrr. 2015.05.009.

del Moral, R. and S. Y. Grishin (1999). "Volcanic disturbances and ecosystem recovery". Ecosystems of Disturbed Ground. Ed. by L. R. Walker, pp. 137-160.

Donovan, A. and C. Oppenheimer (2018). "Imagining the Unimaginable: Communicating Extreme Volcanic Risk". Observing the Volcano World. Ed. by C. J. Fearnley, D. K. Bird, K. Haynes, W. J. McGuire, and G. Jolly. Springer International Publishing. Dor: 10 . 1007/978-3-319-44097-2.

Edwards, K. J., A. J. Dugmore, and J. J. Blackford (2004). "Vegetational response to tephra deposition and land-use change in Iceland: a modern analogue and multiple working hypothesis approach to tephropalynology". Polar Record 40.2, pp. 113-120. DoI: 10.1017 / s0032247403003000.

Felgentreff, C. and T. Glade, eds. (2008). Naturrisiken und Sozialkatastrophen. Spektrum Akademischer Verlag.

Fiedler, L. (1994). Alt-und mittelsteinzeitliche Funde in Hessen. Vol. 2. Theiss.

Fisher, R. V. and H.-U. Schmincke (1984). Pyroclastic rocks. Berlin: Springer-Verlag.

Fournier-Chambrillon, C., D. Maillard, and P. Fournier (1995). "Diet of the wild boar (Sus scrofa L.) inhabiting the Montpellier garrigue". Journal of Mountain Ecology 3.

Frogner Kockum, P. C., R. B. Herbert, and S. R. Gislason (2006). "A diverse ecosystem response to volcanic aerosols". Chemical Geology 231.1-2, pp. 57-66. Dor: 10.1016/ j . chemgeo.2005.12.008.

Fruth, H. (1979). "Ein spätpaläolitischer Fundplatz bei Mühlheim-Dietesheim, Kreis Offenbach". Archäologisches Korrespondenzblatt 9.3, pp. 261-266.

- (1994). "Der spätpaläolithische Fundplatz Mühlheim-Dietesheim, Kreis Offenbach". Fundberichte aus Hessen 22/23.1982-83, pp. 1-67.

Fuchs, S., J. Birkmann, and T. Glade (2012). "Vulnerability assessment in natural hazard and risk analysis: current approaches and future challenges". Natural Hazards 64.3, pp. 1969-1975. DoI: 10.1007/s11069012-0352-9.

Gramsch, B., J. Beran, S. Hanik, and R. S. Sommer (2013). "A Palaeolithic fishhook made of ivory and the earliest fishhook tradition in Europe". Journal of Archaeological Science 40.5, pp. 2458-2463. Dor: 10 . $1016 /$ j . jas.2013.01.010.

Grattan, J. and R. Torrence, eds. (2003). Natural disasters and cultural change. Routledge.

- eds. (2007). Living under the shadow: cultural impacts of volcanic eruptions. Walnut Creek, CA.: Left Coast Press.

Grote, K. (1988). "Die Buntsandsteinabris im südniedersächsischen Bergland bei Gottingen. Erfassung und Untersuchung ihrer ur-und frühgeschichtlichen Nutzung (1983-1987)". Die Kunde 39, pp. 1-43. 
- (1990). "Das Buntsandsteinabri Bettenroder Berg IX im Reinhäuser Wald bei Göttingen-Paläolithikum und Mesolithikum". Archäologisches Korrespondenzblatt 20.2, pp. 137-147.

- (1994). Die Abris im südlichen Leinebergland bei Göttingen: archäologische Befunde zum Leben unter Felsschutzdächern in urgeschichtlicher Zeit. Isensee.

- (2003). “Als die Asche vom Himmel fiel”. Archäologie in Niedersachsen 6, pp. 17-21.

Grote, K. and H. Freese (1982). "Die Felsschutzdächer (Abris) im südniedersächsischen Bergland. Ihre archäologischen Funde und Befunde". Nachrichten aus Niedersachsens Urgeschichte 51, pp. 17-70.

Gudmundsson, G. (2011). "Respiratory health effects of volcanic ash with special reference to Iceland. A review". The Clinical Respiratory Journal 5.1, pp. 2-9. DoI: $10.1111 /$ j . 1752-699x.2010.00231.x.

Herrero, J., I. Irizar, N. A. Laskurain, A. Garcia-Serrano, and R. Garcia-González (2005). "Fruits and roots: Wild boar foods during the cold season in the southwestern Pyrenees". Italian Journal of Zoology 72.1, pp. 49-52. DoI: 10. 1080/11250000509356652.

Hincks, T. K., W. P. Aspinall, P. J. Baxter, A. Searl, R. S. J. Sparks, and G. Woo (2006). "Long term exposure to respirable volcanic ash on Montserrat: a time series simulation". Bulletin of Volcanology 68.3, pp. 266284. Dor: 10.1007 / s00445-005-0006-9.

Hlodversdottir, H., G. Petursdottir, H. K. Carlsen, T. Gislason, and A. Hauksdottir (2016). "Long-term health effects of the Eyjafjallajökull volcanic eruption: a prospective cohort study in 2010 and 2013". BMJ Open 6.9, e011444. DoI: 10 . 1136 / bm jopen 2016-011444.

Hofbauer, H. (1992). "Ein spätpaläolithischer Fundplatz bei Rothenkirchen, Kreis Fulda (Hessen)". Archäologisches Korrespondenzblatt 22.3, pp. 329-340.

Horwell, C., P. Baxter, and R. Kamanyire (2015). "Health impacts of volcanic eruptions". Global Volcanic Hazards and Risk. Ed. by S. C. Loughlin, S. Sparks, S. K. Brown, S. F. Jenkins, and C. Vye-Brown. Cambridge University Press, pp. 289-294. Dor: 10. 1017 / cbo9781316276273.015.

Horwell, C. J. and P. J. Baxter (2006). "The respiratory health hazards of volcanic ash: a review for volcanic risk mitigation". Bulletin of Volcanology 69.1, pp. 124. Dor: 10.1007 / s00445-006-0052-y.

Izdebski, A. et al. (2016). "Realising consilience: How better communication between archaeologists, historians and natural scientists can transform the study of past climate change in the Mediterranean". Quaternary Science Reviews 136, pp. 5-22. DoI: 10.1016/ j . quascirev.2015.10.038.

Jenkins, S., R. Spence, J. Fonseca, R. Solidum, and T. Wilson (2014). "Volcanic risk assessment: Quantifying physical vulnerability in the built environment". Journal of Volcanology and Geothermal Research 276, pp. 105-120. DoI: 10.1016/ j . jvolgeores.2014.03. 002.
Jenkins, S. and R. Spence (2009). "Vulnerability curves for buildings and agriculture". MIAVITA Deliverable Report D 4 .

Jones, S. (2015). "Human vulnerability in a Middle Palaeolithic context: response of hunter-gatherers in India to the Toba supervolcanic eruption 74,000 years ago". Past Vulnerability. Volcanic eruptions and human vulnerability in traditional societies past and present. Ed. by F. Riede. Aarhus: Aarhus University Press, pp. 257-278.

Jöris, O. and T. Terberger (2001). “Zur Rekonstruktion eines Zeltes mit Trapezförmigem Grundriß am Magdalénien-Fundplatz Gönnersdorf/Mittelrhein: Eine „Quadratur des Kreises"?” Archäologisches Korrespondenzblatt 31.2, pp. 163-172.

Knuth, G. and M. Thomae (2003). "Zur Tephra im Alleröd bei Schadeleben und Krumpa in SachsenAnhalt". Hallesches Jahrbuch für Geowissenschaften 25, pp. 81-90.

Latham, J., B. W. Staines, and M. L. Gorman (1999). "Comparative feeding ecology of red (Cervus elaphus) and roe deer (Capreolus capreolus) in Scottish plantation forests". Journal of Zoology 247.3, pp. 409418. DoI: $10.1111 / \mathrm{j} .1469-7998$. 1999 . tb01003.x.

Le Gall, O. (2003). "Des Magdaléniens et...des Poissons". Mode de vie au Magdalénien: Apports de l'archéozoologie [Zooarchaeological insights into Magdalenian lifeways]. Ed. by S. Costamagno and V. Laroulandie. Oxford, England : Archaeopress, pp. 119-128.

Loew, S. (2005). "Der Federmesser-Fundplatz rüsselsheim 122 am unteren main (Hessen)". Archäologisches Korrespondenzblatt 35.2, pp. 143-158.

Lyman, R. L. (1987). "On the Analysis of Vertebrate Mortality Profiles: Sample Size, Mortality Type, and Hunting Pressure". American Antiquity 52.1, p. 125. DoI: $10.2307 / 281064$.

Mania, D. (2003). "Ascheregen vor 13000 Jahren im Elbe-Saalegebiet”. Praehistoria Thuringica 9, pp. 5179.

Maqsood, T., V. Miller, K. Dale, M. Edwards, H. Ryu, and M. Wehner (2014). GAR15 Vulnerability Functions: Reporting on the UNISDR/GA SE Asian Regional Workshop on Structural Vulnerability Models for the GAR Global Risk Assessment, 11-14 November, 2013, Geoscience Australia, Canberra, Australia. Geoscience Australia.

Matrai, K. and P. Kabai (1989). "Winter plant selection by red and roe deer in a forest habitat in Hungary". Acta Theriologica 34.15, pp. 227-234.

McCormick, M., P. E. Dutton, and P. A. Mayewski (2007). "Volcanoes and the Climate Forcing of Carolingian Europe, A.D. 750-950". Speculum 82.4, pp. 865-895. DoI: 10.1017/s0038713400011325.

Muir-Wood, R. (2012). The use of catastrophe loss modelling methodologies to design and monitor disaster resilience goals and indicators in a post-mdg framework. London, UK: Risk Management Solutions. 
Neild, J., P. O’Flaherty, P. Hedley, R. Underwood, D. Johnston, B. Christenson, and P. Brown (1998). "Impact of a volcanic eruption on agriculture and forestry in New Zealand". MAF policy technical paper 99.2, p. 101.

Oppenheimer, C. (2011). Eruptions that shook the world. Cambridge University Press.

Oreskes, N. (2015). "The fact of uncertainty, the uncertainty of facts and the cultural resonance of doubt: Figure 1." Philosophical Transactions of the Royal Society A: Mathematical, Physical and Engineering Sciences 373.2055, p. 20140455. DOI: 10. 1098 / rsta . 2014. 0455.

Pyke, D. A. (1984). "Initial Effects of Volcanic Ash from Mount St. Helens on Peromyscus maniculatus and Microtus montanus". Journal of Mammalogy 65.4, pp. 678-680. Dor: $10.2307 / 1380851$.

Pyle, D. M. (1989). "The thickness, volume and grainsize of tephra fall deposits". Bulletin of Volcanology 51.1, pp. 1-15. Dor: 10. 1007 / bf01086757.

Redman, C. L. (2005). "Resilience Theory in Archaeology". American Anthropologist 107.1, pp. 70-77. DoI: 10.1525/aa.2005.107.1.070.

Riede, F. (2008). "The Laacher See-eruption (12, 920 $\mathrm{BP})$ and material culture change at the end of the Allerød in Northern Europe". Journal of Archaeological Science 35.3, pp. 591-599. Dor: 10.1016/ j . jas . 2007.05 .007$.

- (2012). "Tephrochronologische Nachuntersuchungen am endpaläolithischen Fundplatz Rothenkirchen, Kreis Fulda. Führte der Ausbruch des Laacher See-Vulkans (10966 v. Chr.) zu einer anhaltenden Siedlungslücke in Hessen?" Jahrbuch des nassauischen Vereins für Naturkunde 133, pp. 47-68.

- (2015). "Volcanic eruptions and human vulnerability in traditional societies past and present-towards a palaeosocial volcanology". Past Vulnerability: Vulcanic eruptions and human vulnerability in traditional societies past and present. Ed. by F. Riede. Aarhus: Aarhus University Press, pp. 9-22.

- (2016). "Volcanic activity and human society". Quaternary International 394, pp. 1-5. DoI: $10.1016 / \mathrm{j}$. quaint.2015.08.090.

- (2014a). "The resettlement of northern Europe". The Oxford handbook of the archaeology and anthropology of hunter-gatherers. Ed. by V. Cummings, P. Jordan, and M. Zvelebil. Oxford, UK: Oxford University Press, pp. 556-581.

- (2014b). "Towards a science of past disasters". Natural Hazards 71.1, pp. 335-362. Dor: 10.1007/s11069013-0913-6.

- (2014c). "Volcanic activity". Encyclopedia of Global Archaeology. Ed. by C. Smith. Vol. 11. New York, NY: Springer-Verlag New York, pp. 7657-7666.

- (2017a). "Past-Forwarding Ancient Calamities. Pathways for Making Archaeology Relevant in Disaster Risk Reduction Research". Humanities 6.4, p. 79. DoI: $10.3390 /$ h6040079.
- (2017b). Splendid Isolation: The eruption of the Laacher See volcano and southern Scandinavian Late Glacial hunter-gatherers. Aarhus: Aarhus University Press.

Risch, R. and H. Meller (2013). "Wandel und Kontinuität in Europa und im Mittelmeerraum um 1600 v. Chr". 1600 - Kultureller Umbruch im Schatten des Thera-Ausbruchs?, [1600 - Cultural change in the shadow of the Thera-Eruption?] Ed. by H. Meller, F. Bertemes, H. Bork, and R. Risch, pp. 597-613.

Saaty, T. L. (1980). "The analytic hierarchy process: planning, priority setting, resources allocation". New York: McGraw 281.

Sauer, F. (2018). "Spätpaläolithische Landnutzungsmuster in Bayern". PhD thesis. FriedrichAlexander-Universität Erlangen-Nürnberg.

Scasso, R. A., H. Corbella, and P. Tiberi (1994). "Sedimentological analysis of the tephra from the 12-15 August 1991 eruption of Hudson volcano". Bulletin of Volcanology 56.2, pp. 121-132. DOI: 10 . 1007 / bf 00304107.

Schmincke, H. (2004). Volcanism. Vol. 28. Springer Science \& Business Media.

Schmincke, H., C. Park, and E. Harms (1999). "Evolution and environmental impacts of the eruption of Laacher See Volcano (Germany) 12, 900 a BP”. Quaternary International 61.1, pp. 61-72. DoI: $10.1016 /$ s1040-6182(99)00017-8.

Sheets, P. D. (2012). "Responses to Explosive Volcanic Eruptions by Small to Complex Societies in Ancient Mexico and Central America". Surviving sudden environmental change: answers from archaeology. Ed. by J. Cooper and P. D. Sheets. Boulder, CO: University of Colorado Press.

Sheets, P. D. and D. K. Grayson (1979). Volcanic activity and human ecology. London, UK: Academic Press.

Simkin, T., L. Siebert, and R. J. Blong (2001). "Disasters: Volcano Fatalities-Lessons from the Historical Record". Science 291.5502, pp. 255-255. DOI: 10 . 1126 / science.291.5502.255.

Sommer, R. S., U. Fritz, H. Seppä, J. Ekström, A. Persson, and R. Liljegren (2011). "When the pond turtle followed the reindeer: effect of the last extreme global warming event on the timing of faunal change in Northern Europe". Global Change Biology 17.6, pp. 2049-2053. DOI: 10 . 1111/ j . 1365-2486 . 2011. 02388.x.

Spence, R. J. S., I. Kelman, P. J. Baxter, G. Zuccaro, and S. Petrazzuoli (2005). "Residential building and occupant vulnerability to tephra fall". Natural Hazards and Earth System Science 5.4, pp. 477-494. DoI: 10 . 5194/nhess-5-477-2005.

Staesche, U. (1994). "Die Tierreste aus den Buntsandsteinabris im Leinebergland bei Göttingen". Die Abris im südlichen Leinebergland bei Göttingen. Archäologische Befunde zum Leben unter Felsschutzdächern in urgeschichtlicher Zeit. Ed. by $\mathrm{K}$. Grote, pp. 101-140. 
Stewart, C., D. Johnston, G. Leonard, C. Horwell, T. Thordarson, and S. Cronin (2006). "Contamination of water supplies by volcanic ashfall: A literature review and simple impact modelling". Journal of Volcanology and Geothermal Research 158.3-4, pp. 296306. Dor: 10.1016/ j . jvolgeores.2006.07.002.

Stewart, C., H. M. Craig, S. Gaw, T. Wilson, G. Villarosa, V. Outes, S. Cronin, and C. Oze (2016). "Fate and agricultural consequences of leachable elements added to the environment from the 2011 Cordón Caulle tephra fall". Journal of Volcanology and Geothermal Research 327, pp. 554-570. DoI: 10.1016/ j. jvolgeores.2016.09.017.

Stewart, C., L. Pizzolon, T. Wilson, G. Leonard, D. Dewar, D. Johnston, and S. Cronin (2009). "Can volcanic ash poison water supplies?" Integrated Environmental Assessment and Management 5.4, p. 713. Dor: 10.1897/ ieam_2009-062.1.

Street, M. (1996). "The late glacial faunal assemblage from Endingen, Lkr. Nordvorpommern”. rchäologisches Korrespondenzblatt 26, pp. 33-42.

Street, M., T. Terberger, and J. Orschiedt (2006). "A critical review of the German Paleolithic hominin record". Journal of Human Evolution 51.6, pp. 551579. Dor: 10.1016/ j . jhevol.2006.04.014.

Thorarinsson, S. and D. K. Grayson (1979). "On the damage caused by volcanic eruptions with special reference to tephra and gases". Volcanic activity and human ecology. Ed. by P. D. Sheets and D. K. Grayson. London, UK: Academic Press.

Tixier, H. and P. Duncan (1996). “Are European roe deer browsers? A review of variations in the composition of their diets". Revue d'Écologie.

Walker, G. R. (2011). "Modelling the vulnerability of buildings to wind-a review". Canadian Journal of Civil Engineering 38.9, pp. 1031-1039.

Willerslev, E. et al. (2014). "Fifty thousand years of Arctic vegetation and megafaunal diet". Nature 506.7486, pp. 47-51. DoI: 10.1038/nature 12921.

Wilson, T., J. Cole, S. Cronin, C. Stewart, and D. Johnston (2011). "Impacts on agriculture following the 1991 eruption of Vulcan Hudson, Patagonia: lessons for recovery". Natural Hazards 57.2, pp. 185-212. DOI: $10.1007 / \mathrm{s} 11069-010-9604-8$.

\section{A Appendix 1}

vspace Six important attributes are considered in more detail - human health, shelter, plants as food supply, small animals as food supply, large animals as food supply, and water supply. Each section lists factors which influenced our shaping of the vulnerability curves, and the major references that guided that exercise. Throughout the appendix, $\mu$ is the mean vulnerability of the attribute under consideration, and $\sigma$ represents the standard deviation of the vulnerability of the attribute under consideration.

\section{A.1 Human health}

See Figure A1. Fine tephra grain size with larger proportion $<10 \mu \mathrm{m}$ diameter and/or condensed volatiles rich in acids $\left(\mathrm{H}_{2} \mathrm{SO}_{4}, \mathrm{HCl}, \mathrm{HF}\right)$, polycyclic hydrocarbons and trace metals. Older people more likely to have pre-existing health issues; young children unlikely to have immunity to infections; children (closer to ground) more affected by remobilisation of tephra; old and very young more affected by food supply shortages; stress.

- can increase incidence of acute and chronic respiratory and bronchial irritation, cause premature cardiorespiratory morbidity and mortality, skin irritation (rash/eczema), eye infections;

- high proportion of fine crystalline silica (cristabolite, tridymite, quartz) particles increases likely development of pneumonosilicosis with prolonged exposure;

- possibility that fluoride content will adversely affect humans;

- higher incidence of psychological symptoms and psychiatric morbidity;

- remobilisation of fine particles by wind can exacerbate respiratory illnesses;

- some respiratory and physical symptoms may increase with time after initial exposure (for at least up to a few years).

Key references: Hincks et al. [2006], Horwell and Baxter [2006], Stewart et al. [2006], Gudmundsson [2011], Horwell et al. [2015], and Hlodversdottir et al. [2016]; see also http://www.ivhhn.org.

\section{A.2 Shelter}

See Figure A2.

- roof loads on tent-like structures leading to possible collapse; deterioration of tent-like structures with adverse surface chemistry of tephra;

- rock overhangs offer little protection from fine tephra fall unless raining at time;

- caves offer more shelter.

Key references: Blong [2003], Spence et al. [2005], Jenkins and Spence [2009], Jenkins et al. [2014], Maqsood et al. [2014], and Blong et al. [2017b].

\section{A.3 Food supply}

Food sources affected differentially by tephra fall. 


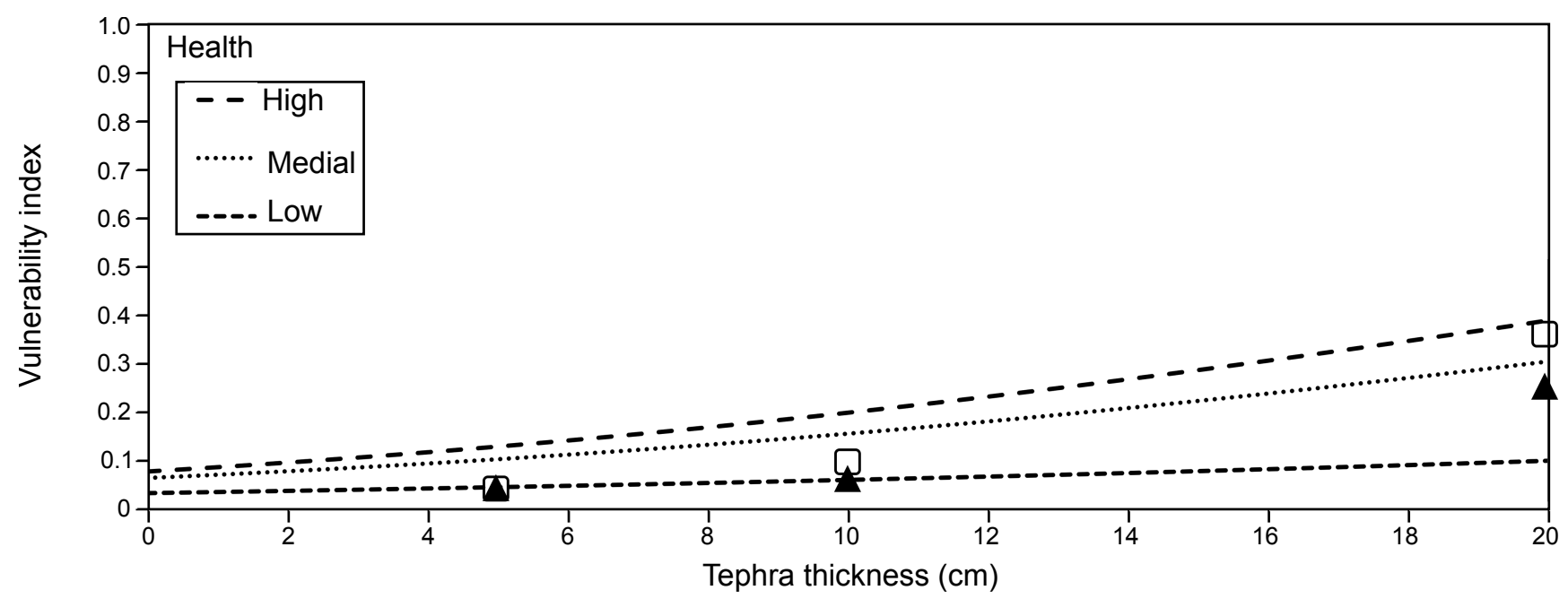

Figure A1: Estimated high, medial, and low health rates for a human Palaeolithic population exposed to 0-20 $\mathrm{cm}$ of tephra fall from the Laacher See eruption. Boxes = Participant A, Triangles = Participant B estimates of vulnerability for 5, 10, and 18-20 cm of compacted tephra.

Table A1 - Fitting parameters for vulnerability curves based on health in Figure A1.

\begin{tabular}{rccc}
\hline Death rates & $\mu$ & $\sigma$ & Curve \\
\hline High & 25.00 & 18.00 & Normal \\
Medial & 30.00 & 20.00 & Normal \\
Low & 70.00 & 40.00 & Normal \\
\hline
\end{tabular}

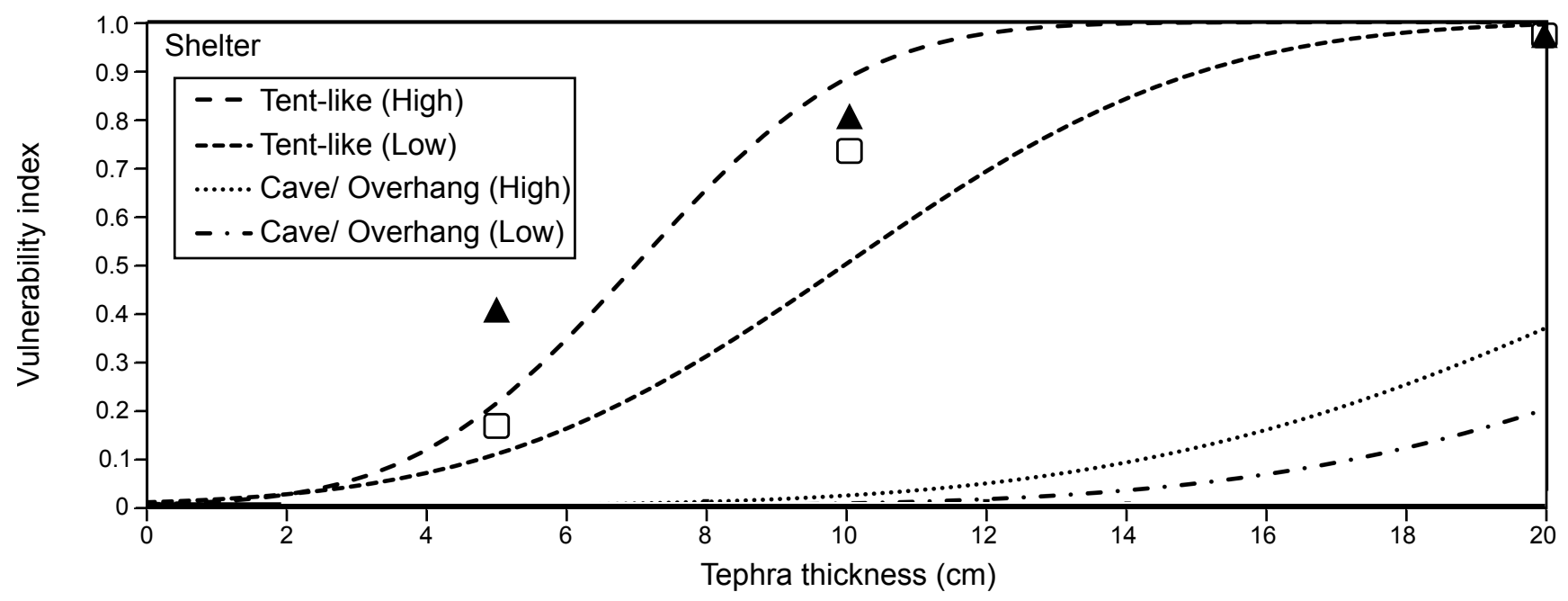

Figure A2: Estimated high and low vulnerability indices for tent-like and cave/overhang shelter types for 0-20 $\mathrm{cm}$ of tephra fall from the Laacher See eruption. Boxes = Participant A, Triangles = Participant B estimates of vulnerability for 5, 10, and 18-20 cm of compacted tephra.

Table A2 - Fitting parameters for vulnerability curves based on shelter in Figure A2.

\begin{tabular}{rccc}
\hline Shelter & $\mu$ & $\sigma$ & Curve \\
\hline Tent-like (high) & 7.00 & 2.50 & Normal \\
Tent-like (low) & 10.00 & 4.00 & Normal \\
Cave or overhang (high) & 22.00 & 6.00 & Normal \\
Cave or overhang (low) & 25.00 & 6.00 & Normal \\
\hline
\end{tabular}




\section{A.3.1 Plants}

\section{See Figure A3.}

- Food growing close to ground buried;

- fine particles stick to seeds and fruit depending on whether surfaces smooth/hairy;

- leaves burnt by acid surface chemistry of ash (salt damage);

- development stage/maturity of plant at ash fall important; differential effects of plant physiognomy;

- plant development stage affects potential branch breakage or canopy loading;

- tephra effect on pollinating insects versus pests;

- plants abraded by remobilisation of tephra;

- wind and rainfall during and after tephra fall can have important consequences;

- possibility that even very thin tephra falls alter forest composition;

- $10 \mathrm{~mm}$ fall might affect growing plants through direct damage, impeded drainage, chemical alteration, or benefit from nutrient inputs of trace elements;

- chemical effects minimised by continual washing by rainfall;

- dormant plants more likely to survive and snowpack may or may not enhance survival with less damage to understory and recovery more rapid.

Key references: Antos and Zobel [1982], Blackford et al. [1992], Neild et al. [1998], del Moral and Grishin [1999], Edwards et al. [2004], Dale et al. [2005], Jenkins and Spence [2009], Arnalds [2013], and Crisafulli et al. [2015].

\section{A.3.2 Small animals}

See Figure A4.

- Feeding habit - omnivorous, herbivorous, or carnivorous;

- arboreal, ground-dwelling, or fossorial;

- food sources above or below ground surface;

- effects of tephra fall (including thickness) on small animal food sources;
- adaptability of small animals to a variety of food sources;

- food palatability;

- effects of feeding habits on quantity of ash ingested on tooth abrasion and on eyesight and skin/fur irritation;

- stability of (increasing/decreasing/stable) preeruption population;

- water availability and quality (taste);

- effects of ash fall on small animal predators;

- seasonality of ashfall and food supply (especially in relation to breeding season);

- post-eruption rainfall and remobilisation of tephra by wind.

Key references: Burt [1961], Andersen [1982], Pyke [1984], Andersen and MacMahon [1985], and Dale et al. [2005].

\section{A.3.3 Large animals}

See Figure A5.

- diversity of food sources for omnivorous large animals such as wild boars - mainly plant matter from aerial parts of plants especially fruits, bracken, some animal carrion, snails and larvae of various invertebrates;

- food selection influenced by energy requirements, food availability, seasonal and geographic variations red and roe deer mainly browse on pines, grasses, forbs and and fruits;

- eye irritation, tooth abrasion, ash ingestion, skin or fur irritation may be important;

- soluble flourine absorbed on tephra grains ingested by animals - can lead to seizures, kidney and liver failure, tooth and bone disintegration; fluorine rapidly flushed by rainfall; maximum impact during prolonged dry weather.

Key references: Lyman [1987], Matrai and Kabai [1989], Fournier-Chambrillon et al. [1995], Tixier and Duncan [1996], Latham et al. [1999], Cronin et al. [2000], Herrero et al. [2005], Wilson et al. [2011], and Ballari and Barrios-Garcia [2013]. 


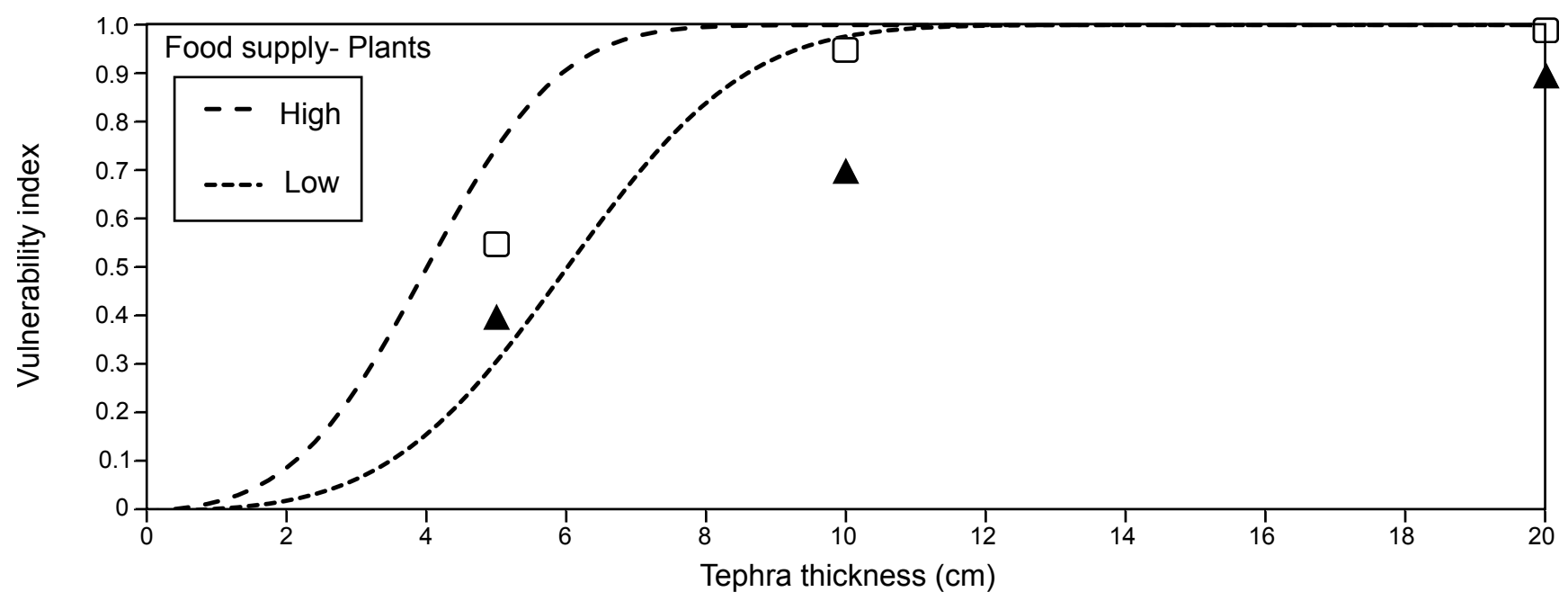

Figure A3: Estimated high and low vulnerability indices for a variety of Group 1 plants exposed to $0-20 \mathrm{~cm}$ of tephra fall from the Laacher See eruption. For example, we have chosen to focus only on plants growing reasonably close to the ground although, Following MIA-VITA [Bignami et al. 2012], Group 1 plants are small herbaceous plants and creepers - plants that we believe were the most likely plant food source for Federmessergruppen people.

Table A3 - Fitting parameters for vulnerability curves based on food supply (plants) in Figure A3.

\begin{tabular}{rccc}
\hline Plants & $\mu$ & $\sigma$ & Curve \\
\hline Group 1 plants (high) & 4.00 & 1.50 & Normal \\
Group 1 plants (low) & 6.00 & 2.00 & Normal \\
\hline
\end{tabular}

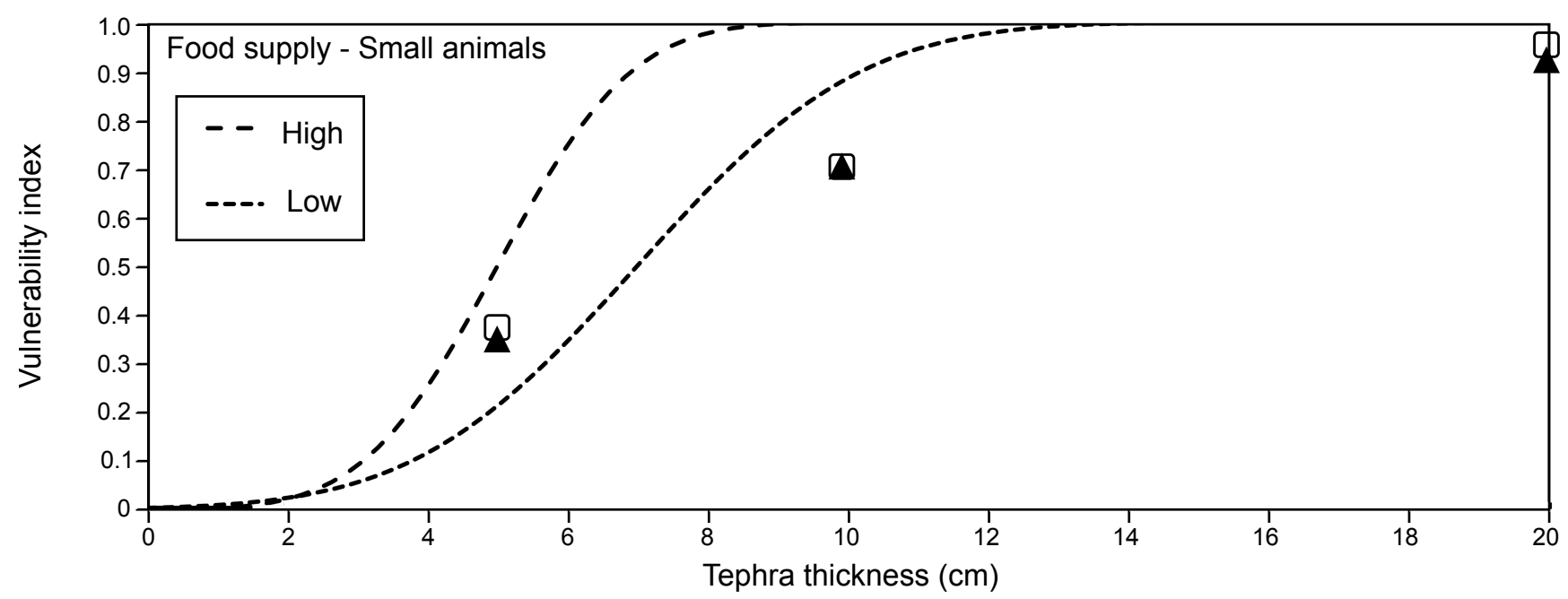

Figure A4: Estimated high and low vulnerability indices for small animals exposed to 0-20 $\mathrm{cm}$ of tephra fall from the Laacher See eruption. Boxes = Participant A, Triangles = Participant B estimates of vulnerability for 5, 10, and $18-20 \mathrm{~cm}$ of compacted tephra.

Table A4 - Fitting parameters for vulnerability curves based on food supply (small animals) in Figure A4.

\begin{tabular}{rccc}
\hline Small animals & $\mu$ & $\sigma$ & Curve \\
\hline High & 5.00 & 1.50 & Normal \\
Low & 7.00 & 2.50 & Normal \\
\hline
\end{tabular}




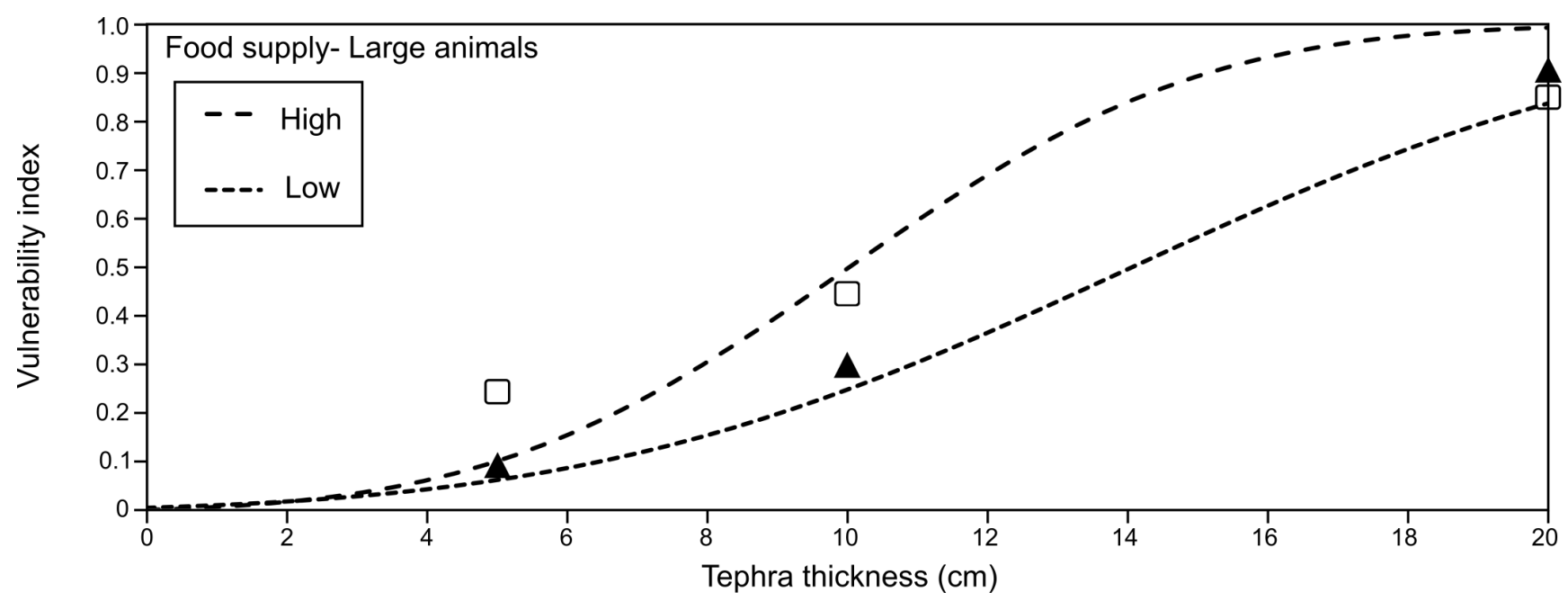

Figure A5: Estimated high and low vulnerability indices large animals exposed to $0-20 \mathrm{~cm}$ of tephra fall from the Laacher See eruption.

Table A5 - Fitting parameters for vulnerability curves based on food supply (large animals) in Figure A5.

\begin{tabular}{rccc}
\hline Large animals & $\mu$ & $\sigma$ & Curve \\
\hline High & 10.00 & 4.00 & Normal \\
Low & 14.00 & 6.00 & Normal \\
\hline
\end{tabular}

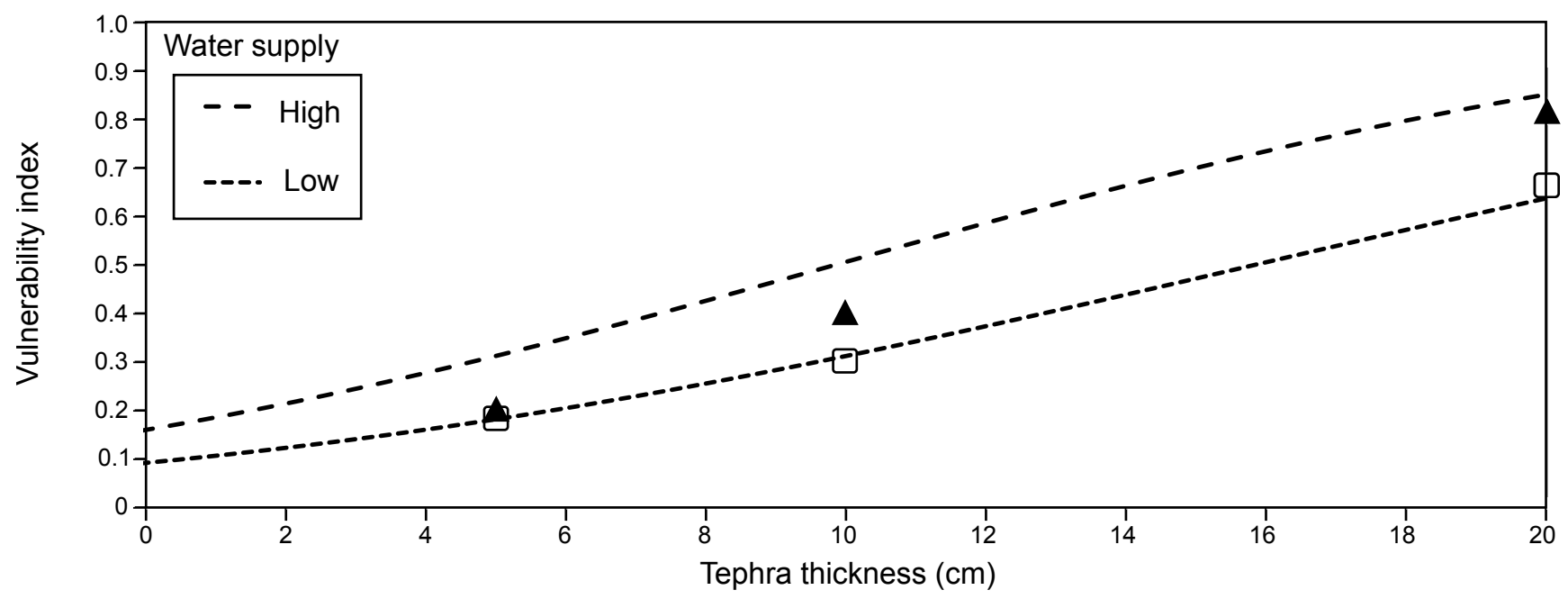

Figure A6: Estimated high and low vulnerabilities of water supply for Federmessergruppen communities exposed to $0-20 \mathrm{~cm}$ of tephra fall from the Laacher See eruption.

Table A6 - Fitting parameters for vulnerability curves based on water supply in Figure A6.

\begin{tabular}{rccc}
\hline Water supply & $\mu$ & $\sigma$ & Curve \\
\hline High & 10.00 & 10.00 & Normal \\
Low & 16.00 & 12.00 & Normal \\
\hline
\end{tabular}

\section{A.4 Water supply}

\section{See Figure A6.}

- An enormous range of surface coatings possible (more than 50?) but $\mathrm{H}_{2} \mathrm{SO}_{4}, \mathrm{HCl}$, and $\mathrm{HF}$ most sig- nificant in promoting acidity;

- Soluble components of ash likely to make surface water supply unpalatable due to metallic taste (and red, brown, black colouration) before water poses a health hazard; 
- Toxic hazards in water supply unlikely unless fluorine content is high;

- Small or large lake, stream, spring; geology may be important. Carbonate-rich geology neutralises added acidity by buffering;

- Turbidity or cloudiness has few direct health effects but can promote bacterial growth;
- Post-ash fall rainfall and ash remobilisation by water and/or wind can affect water supplies, depending on sizes of catchment area and water bodies.

Key references: Stewart et al. [2006], Stewart et al. [2009], and Stewart et al. [2016]. 